\title{
Petrology of the Crazy Mountains Dike Swarm and Geochronology of Associated Sills, South-Central Montana
}

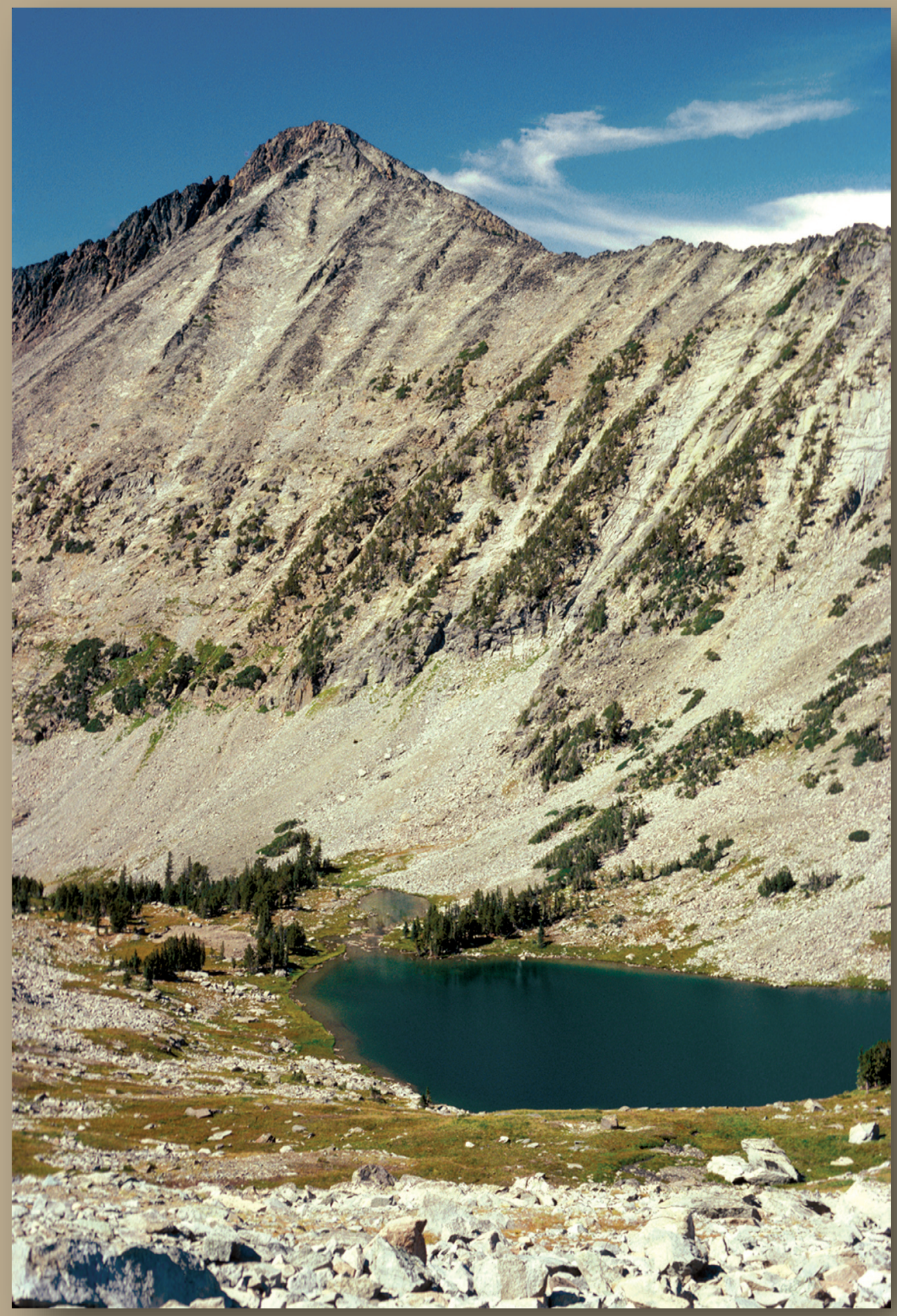

U.S. Department of the Interior U.S. Geological Survey 
Cover. Prominent ridge northwest of Cottonwood Lake, in the Crazy Mountains, south-central Montana, composed of the diorite and gabbro phase of the Big Timber stock and intruded by dikes of the Crazy Mountains dike swarm. 


\section{Petrology of the Crazy Mountains Dike Swarm and Geochronology of Associated Sills, South-Central Montana}

By Edward A. du Bray, Stephen S. Harlan, and Anna B. Wilson

Professional Paper 1715 


\title{
U.S. Department of the Interior \\ Gale A. Norton, Secretary \\ U.S. Geological Survey \\ P. Patrick Leahy, Acting Director
}

U.S. Geological Survey, Reston, Virginia: 2006

\author{
For sale by U.S. Geological Survey Information Services \\ Box 25286, Denver Federal Center \\ Denver, CO 80225 \\ For more information about the USGS and its products: \\ Telephone: 1-888-ASK-USGS \\ World Wide Web: http://www.usgs.gov
}

\footnotetext{
Any use of trade, product, or firm names in this publication is for descriptive purposes only and does not imply endorsement by the U.S. Government.

Although this report is in the public domain, permission must be secured from the individual copyright owners to reproduce any copyrighted materials contained within this report.

Suggested citation:

du Bray, E.A., Harlan, S.S., and Wilson, A.B., 2006, Petrology of the Crazy Mountains dike swarm and geochronology of associated sills, south-central Montana: U.S. Geological Survey Professional Paper 1715, 21 p.
} 


\section{Contents}

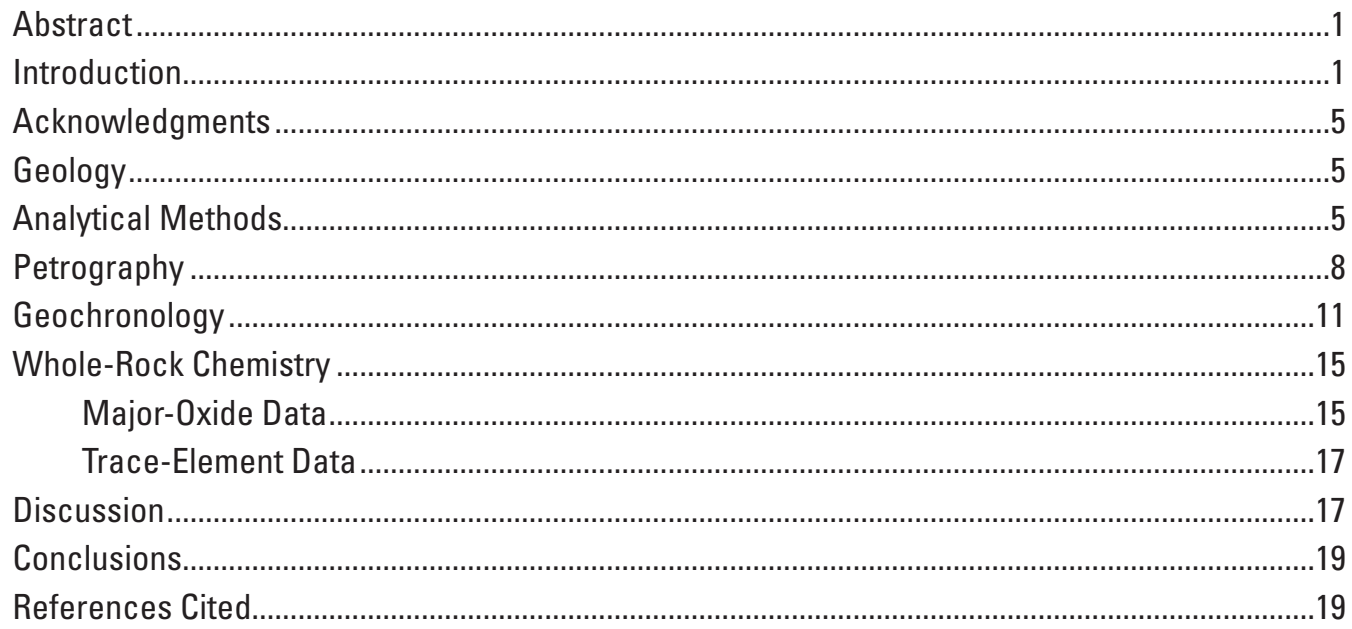

\section{Figures}

1. Maps showing regional geologic setting for the Crazy Mountains dike swarm ...............2

2. Generalized geologic map of the Big Timber stock .....................................................

3. Total alkali-silica variation diagram showing compositions of samples from the Crazy Mountains dike swarm ...............................................................................

4. Graphs showing ${ }^{40} \mathrm{Ar} /{ }^{39} \mathrm{Ar}$ age spectra for hornblende and biotite separates from alkaline intrusive rocks in the Crazy Mountains ...................................................12

5. Variation diagrams showing abundances of major oxides and zirconium in samples from the Crazy Mountains dike swarm .........................................................16

6. Trace-element tectonic setting-discrimination variation diagram for samples from the Crazy Mountains dike swarm

7. Ternary AFM diagram showing compositions of samples from the Crazy Mountains dike swarm ......

8. Ternary variation diagram showing the relative proportions of $\mathrm{Rb}, \mathrm{K}$, and $\mathrm{Sr}$ in samples from the Crazy Mountains dike swarm

\section{Tables}

1. Composition of selected samples of the Crazy Mountains dike swarm ............................6

2. Data for ${ }^{40} \mathrm{Ar} /{ }^{39} \mathrm{Ar}$ step heating of samples of alkaline sills in the Crazy Mountains

3. Summary of isotopic dating results for alkaline sills in the northern Crazy Mountains. 


\title{
Petrology of the Crazy Mountains Dike Swarm and Geochronology of Associated Sills, South-Central Montana
}

\author{
By Edward A. du Bray, Stephen S. Harlan, and Anna B. Wilson
}

\section{Abstract}

The Crazy Mountains dike swarm is a radial array associated with the Eocene (approximately $49 \mathrm{Ma}$ ) Big Timber stock in the Crazy Mountains of south-central Montana. Dikes are hosted by the stock and by Paleocene Fort Union Formation rocks that host the stock. The spatial coincidence, field relations, and similarity of petrographic and geochemical features suggest that the dikes and the stock are cogenetic and coeval. The dikes depict a broad range of compositions, from rhyolite to basalt; dike composition is only weakly related to position relative to the Big Timber stock. The dikes range from 51 to 71 weight percent $\mathrm{SiO}_{2}$, a slightly more restricted range than that exhibited by the stock. Compositional variation among the dikes is less systematic than is characteristic of the stock; dike compositions form more broadly diffuse arrays and tend to be slightly more alkaline. Both of these factors could result from late-stage magmatic-hydrothermal processes that seem to have weakly altered many of the dikes. Major-oxide and trace-element characteristics of the dikes and the associated stock are consistent with a mantle-dominated genesis in a subduction-related volcanic arc setting. In addition to petrologic and geochemical data, new ${ }^{40} \mathrm{Ar} /{ }^{39} \mathrm{Ar}$ geochronologic data for strongly alkaline sills in the northern Crazy Mountains are also presented. Dates for the sills, which are peripheral to the Crazy Mountains dike swarm, indicate that alkaline magmatism was temporally associated with subalkaline magmatism represented by the Big Timber stock and related dikes. Characteristics of the subalkaline magmatism are consistent with renewed volcanic arc magmatism during the Eocene westward hingeline retreat and subsequent southwestward migration of the magmatic front in response to steepening subduction along the western edge of North America.

\section{Introduction}

Numerous alkaline to subalkaline Eocene intrusions are present near the approximate center of the Late Cretaceousearly Tertiary Crazy Mountains Basin of south-central Montana (fig. 1). Most of these intrusions have associated well-developed, cogenetic dike swarms. In this area, the Crazy Mountains dike swarm is associated with the elliptical ( 8 by $13 \mathrm{~km}$ ) Big Timber stock, a composite intrusion that forms the core of the southern Crazy Mountains. The stock is hosted by sedimentary rocks of the Paleocene Fort Union Formation (fig. 2). Thousands of dikes, which constitute the Crazy Mountains dike swarm, intrude the Big Timber stock and its host rock. The dikes are approximately radially oriented relative to the stock. The compositional characteristics and variation of the Crazy Mountains dike swarm are the principal focus of this study.

The Crazy Mountains and the dike swarm have been the subject of numerous geologic investigations. Even in the earliest geologic investigations of the Crazy Mountains, Wolff (1892, 1938) and Larsen (1940) noted the Crazy Mountains dike swarm. Beginning in the early 1960s, University of Cincinnati students initiated a new phase of geologic investigations in this area; in particular, Simms (1966) studied the alkaline rocks in the northern Crazy Mountains, Tappe (1966) mapped the Big Timber stock, and Starmer (1972) studied the Crazy Mountains dike swarm. Subsequently, Dudas (1990, 1991) completed a reconnaissance geochemical study of the Big Timber stock. Then, du Bray and Harlan (1996) completed a detailed study concerning the petrogenesis and geochronology of the Big Timber stock.

The present study is a companion to that of du Bray and Harlan (1996) and pertains to the petrology of the Crazy Mountains dike swarm and the relationship between the dike swarm and the stock. In addition, we present new ${ }^{40} \mathrm{Ar} /{ }^{39} \mathrm{Ar}$ geochronologic data for alkaline intrusions, primarily in the northern Crazy Mountains, which complement ${ }^{40} \mathrm{Ar} /{ }^{39} \mathrm{Ar}$ geochronologic data for the Big Timber stock previously published by du Bray and Harlan (1996). Because Dudas (1990, 1991) presented and interpreted significant compositional data for the alkaline dikes and sills, the petrology and geochemistry of these rocks are not further addressed in this paper.

The Crazy Mountains dike swarm and associated Big Timber stock are components of the Eocene central Montana alkalic province of Larsen (1940) and Chadwick (1972) and are temporally related to the Eocene Challis igneous episode of Armstrong (1978). Like other igneous centers in the central Montana alkalic province, igneous rocks in the 


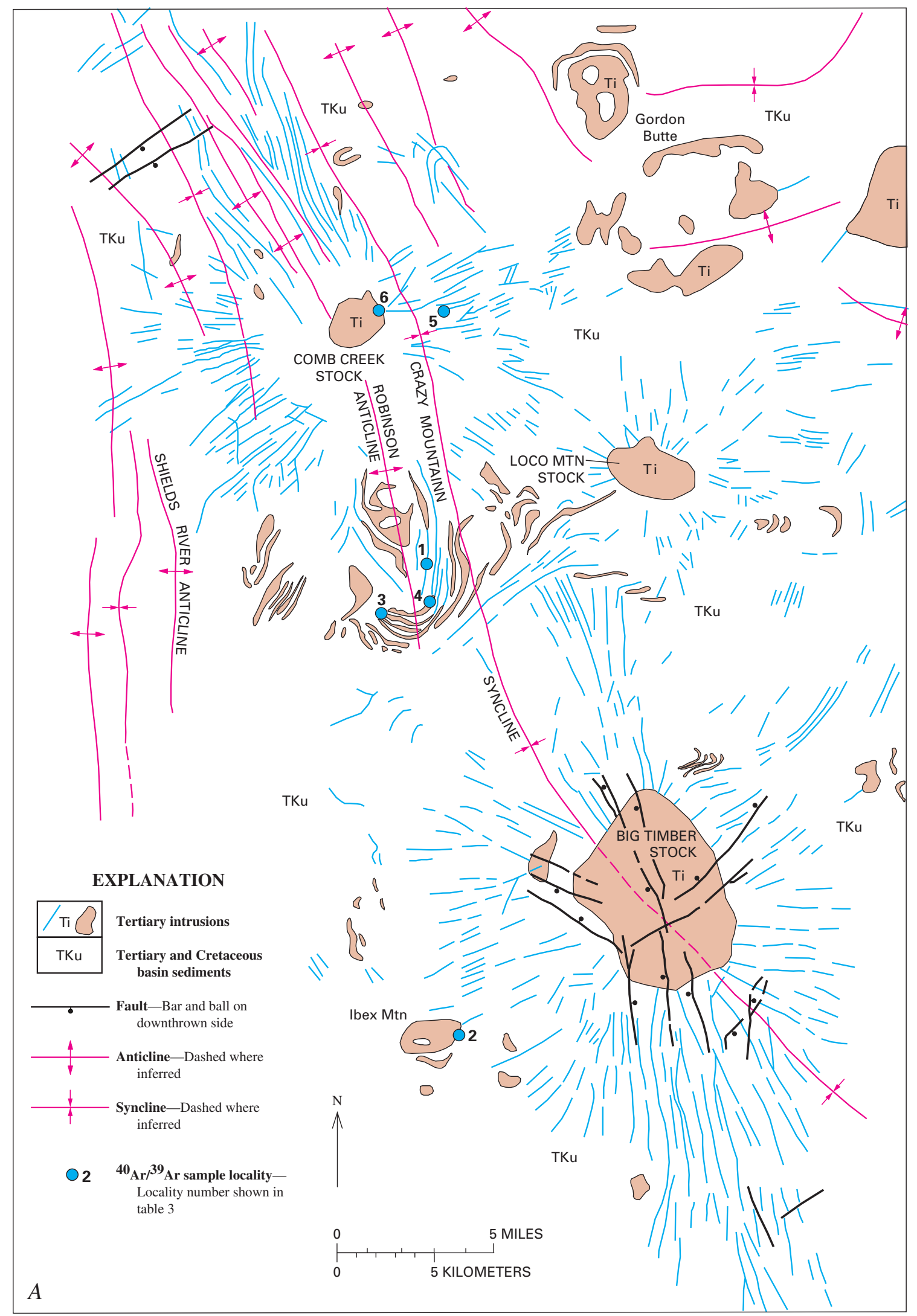

Figure 1. Regional geologic setting for the Crazy Mountains dike swarm, south-central Montana. $A$, Generalized geologic map of the Crazy Mountains showing sites of geochronologically analyzed intrusions. $B$, Index map for figure $1 A$, showing tectonic elements of the Crazy Mountains Basin. Both modified from Roberts (1972). 




\section{EXPLANATION}

Tertiary and Cretaceous intrusive rocks

Tertiary Fort Union Formation

Cretaceous volcanic and volcaniclastic strata (Sliderock Mountain volcano)

Cretaceous volcaniclastic rocks (Livingston Group)

Phanerozoic sedimentary rocks

Proterozoic Belt Supergroup

Archean crystalline basement rocks

Fault — Bar and ball on downthrown side

$\perp$ Thrust fault

4 Anticline-Dashed where

inferred

†ि Overturned anticline

$\downarrow+\underset{\substack{\text { Syncline_-Dashed where } \\ \text { inferred }}}{\downarrow}$ 


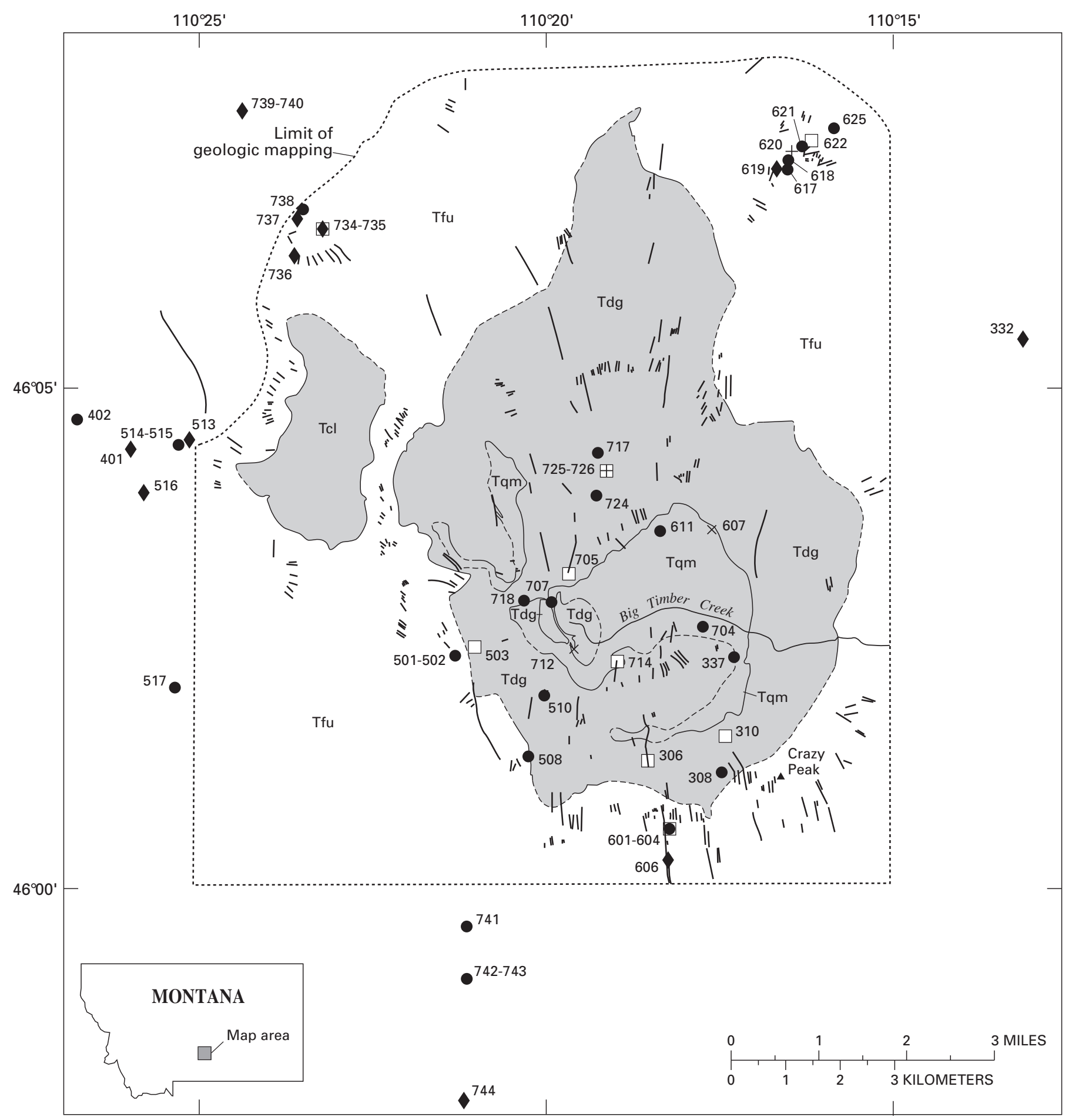

\section{EXPLANATION}

Big Timber stock (Tertiary)

Sample Locality

\begin{tabular}{|c|}
\hline Tcl \\
\hline Tqm \\
\hline Tdg \\
\hline Tfu \\
\hline
\end{tabular}

Campfire Lake apophysis

$\times \quad$ Rhyolite

Quartz monzodiorite

Trachyte/dacite

Diorite and gabbro

Fort Union Formation (Tertiary)

- Trachyandesite/andesite

Contact—Dashed where approximately 
Crazy Mountains occur in an isolated range east of the Rocky Mountain front. Other Eocene igneous rocks in the region include subduction-related volcanic arc rocks in the Highwood Mountains (O’Brien and others, 1991, 1995), north of the Crazy Mountains, the voluminous Challis Volcanic Group in eastern Idaho (Hardyman, 1989; Janecke and Snee, 1993), and rocks of the Absaroka-Gallatin volcanic province (Smedes and Prostka, 1972; Feeley, 2003). The Big Timber stock is located near the southeast margin of the southwardextending magmatic belt delineated by Armstrong and Ward (1991) for the interval 55-40 Ma. The petrogenesis and tectonic implications of the stock and its dike swarm, representing a discrete igneous center located well east of most late Mesozoic-early Cenozoic, subduction-related magmatism in western North America, are noteworthy and are briefly discussed in this study.

\section{Acknowledgments}

Geologic mapping and sample collection for this study were by E.A. du Bray, J.E. Elliott, A.B. Wilson, B.S. Van Gosen, and L.A. Rosenberg during 1992 as part of a mineral resource assessment of the Custer and Gallatin National Forests. Constructive reviews by Karen Lund and R.G. Tysdal considerably helped the accuracy and clarity of this study.

\section{Geology}

The oldest rocks in the central Crazy Mountains are those of the Paleocene Fort Union Formation, a succession of nonmarine sedimentary rocks at least 2,000 m thick that is principally composed of interbedded siltstone, mudstone, sandstone, and, locally, pebble conglomerate (Roberts, 1972). The Fort Union Formation, which hosts the dike swarm and the Big Timber stock, was thermally metamorphosed to hornfels as much as several kilometers from its contact with the stock. Metamorphism associated with stock emplacement is restricted to development of a narrow hornfels aureole; chlorite, formed by recrystallization of clay-rich matrix material, is present in some places. Metamorphism associated with dike emplacement is not apparent.

Du Bray and others (1993) defined two phases of the Big Timber stock (fig. 2). The volumetrically predominant phase

Figure 2 (facing page). Generalized geologic map of the Big Timber stock, south-central Montana (modified from du Bray and others, 1993). Numbered symbols show compositions and sample localities for chemically analyzed dikes. Numbers on map correspond to last three digits (for example, 513) of sample numbers (for example, 202513) in table 1. is medium- to coarse-grained diorite and gabbro (Streckeisen, 1973). The core, or inner part, of the composite stock is fine- to medium-grained quartz monzodiorite that forms an irregularly shaped intrusion, including several large dike- or sill-like extensions; the two phases of the stock are marked by a sharp contact. Cross-cutting relations indicate that the quartz monzodiorite phase was emplaced after solidification of the diorite and gabbro phase. Du Bray and Harlan (1996) presented detailed petrologic and geochronologic data for the stock and its components.

Magmatism associated with the Big Timber stock also involved emplacement of a well-developed dike swarm. The dikes are several centimeters to several tens of meters wide and as much as several kilometers long. The number of dikes that intrude the quartz monzodiorite phase is less than that in the diorite and gabbro phase; most dikes are contemporaneous with, or older than, the quartz monzodiorite phase. The broad range of dike compositions, including rhyolite, trachydacite/ dacite, trachyandesite/andesite, basaltic trachyandesite/basaltic andesite, and trachybasalt, display only weakly systematic spatial distribution (fig. 2). Rhyolite dikes are present only near the stock's core. Most of the trachydacite/dacite dikes crop out in the diorite and gabbro phase of the Big Timber stock, within $1.5 \mathrm{~km}$ of its contact with the inner, quartz monzodiorite phase. Basaltic trachyandesite/basaltic andesite dikes crop out exclusively in the Fort Union Formation, in most cases more than $3 \mathrm{~km}$ from the outer edge of the Big Timber stock. Trachybasalt and trachyandesite/andesite dikes do not seem to be systematically distributed. In addition, dikes of multiple compositions may be present at any sample site. Diagnostic cross-cutting relations are relatively rare, so relative age relations between dikes of various compositions are indeterminate. As suggested by Roberts (1972), dikes of the swarm (fig. 2) form a crudely radial pattern with respect to the Big Timber stock (du Bray and others, 1993). Starmer (1972) provided additional data concerning the outcrop character, distribution, and structural and tectonic features of the dike swarm.

\section{Analytical Methods}

In order to develop representative petrographic and compositional data for the Crazy Mountains dike swarm, 52 dike samples were collected (fig. 2). All geochemical analyses (table 1) were performed in analytical laboratories of the U.S. Geological Survey in Denver, Colo. Major-oxides were analyzed (analysts, D.F. Siems and J.S. Mee) by X-ray fluorescence techniques (Taggart and others, 1987). Ratios of $\mathrm{Fe}^{2+}$ :total iron as $\mathrm{Fe}^{2+}$ were adjusted to 0.90 and major-oxide abundances recalculated to 100 percent, volatile free. E.A. du Bray determined abundances of $\mathrm{Rb}, \mathrm{Sr}, \mathrm{Y}, \mathrm{Zr}, \mathrm{Nb}$, and $\mathrm{Ba}$ by energy-dispersive $\mathrm{X}$-ray fluorescence spectroscopy (Elsass and du Bray, 1982; Yager and Quick, 1992) using ${ }^{109} \mathrm{Cd}$ and ${ }^{241} \mathrm{Am}$ radio-isotope excitation sources. The major-oxide compositions of these samples were classified (fig. 3) as volcanic rocks according to the nomenclature of Le Bas and others (1986). 
Table 1. Composition of selected samples of the Crazy Mountains dike swarm, south-central Montana.

[Note: Major-oxide data in weight percent (normalized to 100 percent, anhydrous); trace-element data in parts per million. Ferrous iron/total iron as FeO adjusted to 0.9. LOI, loss on ignition; bdl, below detection limit]

\begin{tabular}{|c|c|c|c|c|c|c|c|c|c|c|c|}
\hline Sample & 202306 & 202308 & 202310 & 202332 & 202337 & 202401 & 202402 & 202501 & 202502 & 202503 & 202508 \\
\hline $\mathrm{SiO}_{2}$ & 63.44 & 59.16 & 62.51 & 56.57 & 57.87 & 55.31 & 58.35 & 58.05 & 59.31 & 67.02 & 59.26 \\
\hline $\mathrm{Al}_{2} \mathrm{O}_{3}$ & 16.12 & 16.10 & 18.05 & 18.72 & 14.77 & 17.19 & 17.29 & 16.34 & 18.31 & 16.17 & 17.69 \\
\hline $\mathrm{Fe}_{2} \mathrm{O}_{3}$ & 0.54 & 0.74 & 0.47 & 0.73 & 0.93 & 0.94 & 0.81 & 0.74 & 0.60 & 0.37 & 0.51 \\
\hline $\mathrm{FeO}$ & 4.40 & 5.99 & 3.79 & 5.95 & 7.53 & 7.63 & 6.57 & 6.02 & 4.84 & 3.01 & 4.15 \\
\hline $\mathrm{MgO}$ & 2.58 & 2.91 & 1.43 & 3.17 & 5.26 & 4.08 & 2.68 & 4.01 & 2.12 & 1.12 & 2.38 \\
\hline $\mathrm{CaO}$ & 3.86 & 4.94 & 3.83 & 7.92 & 5.42 & 7.48 & 5.74 & 5.80 & 5.35 & 2.41 & 6.67 \\
\hline $\mathrm{Na}_{2} \mathrm{O}$ & 4.55 & 4.93 & 4.83 & 3.37 & 3.71 & 3.29 & 3.68 & 4.15 & 4.46 & 4.36 & 4.14 \\
\hline $\mathrm{K}_{2} \mathrm{O}$ & 3.14 & 3.24 & 3.73 & 1.90 & 2.87 & 2.12 & 2.96 & 2.96 & 3.39 & 4.61 & 3.57 \\
\hline $\mathrm{TiO}_{2}$ & 0.99 & 1.41 & 0.96 & 1.11 & 1.10 & 1.26 & 1.34 & 1.37 & 1.09 & 0.64 & 1.13 \\
\hline $\mathrm{P}_{2} \mathrm{O}_{5}$ & 0.30 & 0.48 & 0.33 & 0.43 & 0.38 & 0.53 & 0.45 & 0.44 & 0.43 & 0.21 & 0.43 \\
\hline $\mathrm{MnO}$ & 0.08 & 0.09 & 0.07 & 0.12 & 0.15 & 0.16 & 0.13 & 0.12 & 0.11 & 0.07 & 0.08 \\
\hline LOI & 1.95 & 0.76 & 1.16 & 2.16 & 0.45 & 1.77 & 2.41 & 0.05 & bdl & 0.33 & 0.16 \\
\hline $\mathrm{Rb}$ & 58 & 57 & 77 & 27 & 83 & 29 & 65 & 68 & 76 & 125 & 53 \\
\hline $\mathrm{Sr}$ & 804 & 1,003 & 788 & 1,090 & 726 & 994 & 791 & 1,053 & 1,008 & 493 & 885 \\
\hline Y & 16 & 22 & 29 & 28 & 24 & 34 & 35 & 23 & 27 & 14 & 30 \\
\hline $\mathrm{Zr}$ & 185 & 198 & 275 & 149 & 237 & 176 & 202 & 179 & 173 & 328 & 208 \\
\hline $\mathrm{Nb}$ & 16 & 20 & 29 & 21 & 14 & 25 & 22 & 25 & 22 & 16 & 2 \\
\hline $\mathrm{Ba}$ & 1,567 & 1,897 & 1,806 & 1,338 & 1,418 & 1,643 & 1,526 & 1,698 & 1,632 & 1,341 & 1,611 \\
\hline $\mathrm{La}$ & 46 & 68 & 60 & 47 & 72 & 63 & 55 & 53 & 62 & 49 & 42 \\
\hline $\mathrm{Ce}$ & 70 & 99 & 110 & 90 & 86 & 103 & 85 & 96 & 92 & 86 & 78 \\
\hline $\mathrm{Nd}$ & 32 & 22 & 62 & 24 & 55 & 66 & 30 & 19 & 32 & 28 & 59 \\
\hline Sample & 202510 & 202513 & 202514 & 202515 & 202516 & 202517 & 202601 & 202602 & 202603 & 202604 & 202606 \\
\hline $\mathrm{SiO}_{2}$ & 56.28 & 55.50 & 58.08 & 59.77 & 53.39 & 57.62 & 58.44 & 65.23 & 58.33 & 57.44 & 53.95 \\
\hline $\mathrm{Al}_{2} \mathrm{O}_{3}$ & 16.23 & 16.62 & 17.49 & 17.86 & 16.16 & 16.32 & 17.24 & 17.00 & 16.77 & 17.71 & 16.46 \\
\hline $\mathrm{Fe}_{2} \mathrm{O}_{3}$ & 0.85 & 0.91 & 0.74 & 0.70 & 0.98 & 0.80 & 0.79 & 0.40 & 0.78 & 0.77 & 1.04 \\
\hline $\mathrm{FeO}$ & 6.90 & 7.38 & 5.98 & 5.70 & 7.92 & 6.51 & 6.39 & 3.21 & 6.35 & 6.25 & 8.39 \\
\hline $\mathrm{MgO}$ & 4.38 & 4.86 & 3.17 & 2.08 & 5.35 & 4.45 & 2.84 & 1.15 & 3.56 & 2.27 & 4.68 \\
\hline $\mathrm{CaO}$ & 6.20 & 7.21 & 5.25 & 5.12 & 7.84 & 6.63 & 5.39 & 2.47 & 5.49 & 5.41 & 5.96 \\
\hline $\mathrm{Na}_{2} \mathrm{O}$ & 4.00 & 3.24 & 4.17 & 4.19 & 3.86 & 3.22 & 4.31 & 5.05 & 4.25 & 4.81 & 4.85 \\
\hline $\mathrm{K}_{2} \mathrm{O}$ & 3.29 & 2.31 & 3.28 & 3.06 & 2.41 & 2.82 & 2.78 & 4.35 & 2.94 & 3.27 & 2.15 \\
\hline $\mathrm{TiO}_{2}$ & 1.32 & 1.39 & 1.27 & 0.89 & 1.12 & 1.09 & 1.23 & 0.86 & 1.00 & 1.17 & 1.80 \\
\hline $\mathrm{P}_{2} \mathrm{O}_{5}$ & 0.45 & 0.45 & 0.45 & 0.50 & 0.81 & 0.40 & 0.46 & 0.23 & 0.41 & 0.77 & 0.57 \\
\hline $\mathrm{MnO}$ & 0.09 & 0.13 & 0.12 & 0.13 & 0.16 & 0.12 & 0.12 & 0.05 & 0.11 & 0.13 & 0.16 \\
\hline LOI & 3.38 & 2.74 & 2.20 & 1.79 & 1.89 & 1.89 & 0.44 & 1.43 & 0.68 & 2.56 & 1.44 \\
\hline $\mathrm{Rb}$ & 74 & 40 & 69 & 69 & 28 & 43 & 71 & 87 & 47 & 59 & 42 \\
\hline $\mathrm{Sr}$ & 762 & 817 & 895 & 925 & 2,059 & 664 & 860 & 575 & 987 & 1,312 & 897 \\
\hline Y & 22 & 20 & 30 & 31 & 36 & 13 & 16 & 18 & 24 & 21 & 25 \\
\hline $\mathrm{Zr}$ & 195 & 157 & 189 & 182 & 147 & 114 & 210 & 306 & 161 & 264 & 173 \\
\hline $\mathrm{Nb}$ & 23 & 14 & 29 & 17 & 28 & 15 & 23 & 28 & 16 & 30 & 30 \\
\hline $\mathrm{Ba}$ & 1,450 & 1,205 & 1,577 & 1,674 & 2,658 & 1,448 & 1,470 & 2,063 & 2,255 & 1,924 & 1,301 \\
\hline $\mathrm{La}$ & 28 & 48 & 55 & 53 & 125 & 45 & 44 & 59 & 48 & 67 & 50 \\
\hline $\mathrm{Ce}$ & 75 & 82 & 111 & 103 & 230 & 77 & 74 & 118 & 83 & 121 & 93 \\
\hline $\mathrm{Nd}$ & 33 & 29 & 51 & 60 & 77 & 45 & 22 & 46 & 51 & 66 & 45 \\
\hline
\end{tabular}


Table 1. Composition of selected samples of the Crazy Mountains dike swarm, south-central Montana.-Continued

\begin{tabular}{|c|c|c|c|c|c|c|c|c|c|c|c|}
\hline Sample & 202607 & 202611 & 202617 & 202618 & 202619 & 202620 & 202621 & 202622 & 202625 & 202704 & 202705 \\
\hline $\mathrm{SiO}_{2}$ & 69.62 & 56.58 & 55.31 & 59.66 & 54.14 & 51.27 & 61.17 & 62.61 & 57.24 & 56.98 & 69.30 \\
\hline $\mathrm{Al}_{2} \mathrm{O}_{3}$ & 15.90 & 18.28 & 17.22 & 18.91 & 14.09 & 16.06 & 17.18 & 17.18 & 16.68 & 17.00 & 15.39 \\
\hline $\mathrm{Fe}_{2} \mathrm{O}_{3}$ & 0.22 & 0.72 & 0.98 & 0.54 & 0.89 & 1.20 & 0.66 & 0.56 & 0.87 & 0.86 & 0.28 \\
\hline $\mathrm{FeO}$ & 1.77 & 5.81 & 7.92 & 4.36 & 7.21 & 9.73 & 5.38 & 4.50 & 7.04 & 6.99 & 2.27 \\
\hline $\mathrm{MgO}$ & 1.01 & 2.35 & 3.62 & 1.84 & 8.23 & 5.48 & 2.35 & 1.70 & 3.54 & 3.02 & 1.40 \\
\hline $\mathrm{CaO}$ & 2.73 & 5.34 & 5.14 & 4.62 & 8.42 & 8.07 & 4.56 & 3.66 & 5.31 & 5.71 & 3.63 \\
\hline $\mathrm{Na}_{2} \mathrm{O}$ & 4.53 & 5.30 & 3.72 & 4.93 & 2.85 & 3.04 & 4.46 & 5.15 & 3.94 & 4.42 & 3.19 \\
\hline $\mathrm{K}_{2} \mathrm{O}$ & 3.67 & 3.38 & 4.00 & 3.54 & 2.51 & 2.63 & 2.92 & 3.50 & 3.66 & 2.78 & 3.91 \\
\hline $\mathrm{TiO}_{2}$ & 0.38 & 1.55 & 1.41 & 1.10 & 1.07 & 1.93 & 0.76 & 0.59 & 1.00 & 1.62 & 0.45 \\
\hline $\mathrm{P}_{2} \mathrm{O}_{5}$ & 0.15 & 0.59 & 0.54 & 0.43 & 0.44 & 0.44 & 0.45 & 0.42 & 0.59 & 0.48 & 0.15 \\
\hline $\mathrm{MnO}$ & 0.03 & 0.08 & 0.15 & 0.08 & 0.14 & 0.16 & 0.11 & 0.13 & 0.13 & 0.14 & 0.05 \\
\hline LOI & 4.30 & 0.04 & 2.48 & 2.74 & 3.19 & 4.04 & 1.55 & 1.37 & 1.21 & 2.44 & 5.21 \\
\hline $\mathrm{Rb}$ & 58 & 69 & 81 & 68 & 54 & 66 & 56 & 60 & 68 & 45 & 55 \\
\hline $\mathrm{Sr}$ & 772 & 1,192 & 700 & 925 & 764 & 842 & 1,018 & 1,418 & 1,242 & 904 & 665 \\
\hline Y & 6 & 28 & 27 & 22 & 14 & 29 & 26 & 39 & 28 & 21 & 8 \\
\hline $\mathrm{Zr}$ & 105 & 206 & 157 & 225 & 147 & 131 & 194 & 230 & 198 & 147 & 113 \\
\hline $\mathrm{Nb}$ & 8 & 25 & 19 & 21 & 17 & 20 & 18 & 39 & 14 & 29 & 12 \\
\hline $\mathrm{Ba}$ & 2,680 & 1,826 & 1,812 & 1,960 & 1,270 & 1,097 & 2,263 & 3,104 & 2,292 & 1,297 & 2,658 \\
\hline $\mathrm{La}$ & 40 & 86 & 74 & 79 & 42 & 31 & 64 & 143 & 85 & 63 & 47 \\
\hline $\mathrm{Ce}$ & 45 & 108 & 88 & 114 & 117 & 67 & 112 & 189 & 105 & 111 & 51 \\
\hline $\mathrm{Nd}$ & 26 & 42 & 36 & 40 & 36 & 34 & 39 & 77 & 66 & 16 & 37 \\
\hline Sample & 202707 & 202712 & 202714 & 202717 & 202718 & 202724 & 202725 & 202726 & 202734 & 202735 & 202736 \\
\hline $\mathrm{SiO}_{2}$ & 60.75 & 70.81 & 64.53 & 60.11 & 61.66 & 58.68 & 51.06 & 68.33 & 63.34 & 55.20 & 55.89 \\
\hline $\mathrm{Al}_{2} \mathrm{O}_{3}$ & 16.09 & 15.18 & 16.49 & 17.94 & 15.73 & 16.48 & 14.56 & 15.59 & 17.04 & 17.29 & 16.58 \\
\hline $\mathrm{Fe}_{2} \mathrm{O}_{3}$ & 0.62 & 0.24 & 0.47 & 0.61 & 0.59 & 0.78 & 1.37 & 0.35 & 0.54 & 0.88 & 0.85 \\
\hline $\mathrm{FeO}$ & 5.03 & 1.96 & 3.83 & 4.94 & 4.75 & 6.34 & 11.12 & 2.83 & 4.35 & 7.11 & 6.91 \\
\hline $\mathrm{MgO}$ & 3.30 & 0.59 & 1.69 & 2.23 & 3.96 & 3.51 & 6.61 & 1.83 & 1.57 & 4.45 & 5.17 \\
\hline $\mathrm{CaO}$ & 4.57 & 1.84 & 3.53 & 4.83 & 4.74 & 5.37 & 6.83 & 2.43 & 4.01 & 7.40 & 6.93 \\
\hline $\mathrm{Na}_{2} \mathrm{O}$ & 4.76 & 4.55 & 4.85 & 4.27 & 4.24 & 4.12 & 3.30 & 3.80 & 4.66 & 3.39 & 3.19 \\
\hline $\mathrm{K}_{2} \mathrm{O}$ & 3.20 & 4.25 & 3.42 & 3.43 & 2.89 & 2.81 & 2.15 & 4.15 & 3.38 & 2.48 & 2.67 \\
\hline $\mathrm{TiO}_{2}$ & 1.22 & 0.40 & 0.76 & 1.11 & 0.99 & 1.45 & 2.08 & 0.49 & 0.56 & 1.24 & 1.25 \\
\hline $\mathrm{P}_{2} \mathrm{O}_{5}$ & 0.38 & 0.13 & 0.34 & 0.42 & 0.36 & 0.38 & 0.74 & 0.16 & 0.42 & 0.42 & 0.43 \\
\hline $\mathrm{MnO}$ & 0.08 & 0.05 & 0.08 & 0.10 & 0.09 & 0.08 & 0.19 & 0.04 & 0.12 & 0.13 & 0.13 \\
\hline LOI & 1.59 & 0.08 & 0.06 & 1.59 & 2.79 & 0.50 & 1.56 & 2.53 & 0.72 & 1.84 & 2.55 \\
\hline $\mathrm{Rb}$ & 67 & 97 & 70 & 81 & 50 & 56 & 70 & 66 & 72 & 51 & 58 \\
\hline $\mathrm{Sr}$ & 687 & 660 & 949 & 834 & 823 & 867 & 798 & 876 & 1,249 & 1,011 & 868 \\
\hline $\mathrm{Y}$ & 21 & 13 & 18 & 28 & 16 & 17 & 30 & 12 & 31 & 23 & 21 \\
\hline $\mathrm{Zr}$ & 180 & 204 & 216 & 189 & 185 & 161 & 152 & 113 & 210 & 167 & 160 \\
\hline $\mathrm{Nb}$ & 22 & 24 & 30 & 23 & 23 & 23 & 20 & 13 & 24 & 17 & 18 \\
\hline $\mathrm{Ba}$ & 1,754 & 2,177 & 2,077 & 1,693 & 1,988 & 1,687 & 868 & 2,723 & 2,619 & 1,536 & 1,449 \\
\hline $\mathrm{La}$ & 66 & 58 & 84 & 70 & 55 & 46 & 56 & 47 & 73 & 51 & 52 \\
\hline $\mathrm{Ce}$ & 85 & 85 & 112 & 78 & 84 & 63 & 91 & 60 & 129 & 86 & 86 \\
\hline $\mathrm{Nd}$ & 55 & 48 & 52 & 72 & 28 & 37 & 50 & 34 & 29 & 35 & 43 \\
\hline
\end{tabular}


Table 1. Composition of selected samples of the Crazy Mountains dike swarm, south-central Montana.-Continued

\begin{tabular}{lrrrrrrrr}
\hline Sample & $\mathbf{2 0 2 7 3 7}$ & $\mathbf{2 0 2 7 3 8}$ & $\mathbf{2 0 2 7 3 9}$ & $\mathbf{2 0 2 7 4 0}$ & $\mathbf{2 0 2 7 4 1}$ & $\mathbf{2 0 2 7 4 2}$ & $\mathbf{2 0 2 7 4 3}$ & $\mathbf{2 0 2 7 4 4}$ \\
$\mathrm{SiO}_{2}$ & 53.03 & 55.74 & 54.33 & 54.57 & 58.51 & 57.01 & 57.20 & 56.68 \\
$\mathrm{Al}_{2} \mathrm{O}_{3}$ & 14.37 & 16.03 & 18.63 & 16.04 & 16.97 & 17.51 & 16.67 & 17.44 \\
$\mathrm{Fe}_{2} \mathrm{O}_{3}$ & 1.09 & 0.92 & 0.87 & 0.98 & 0.76 & 0.83 & 0.86 & 0.89 \\
$\mathrm{FeO}$ & 8.81 & 7.45 & 7.08 & 7.94 & 6.17 & 6.76 & 7.00 & 7.24 \\
$\mathrm{MgO}$ & 8.13 & 4.51 & 3.43 & 5.22 & 3.51 & 3.04 & 3.59 & 3.66 \\
$\mathrm{CaO}$ & 8.22 & 5.67 & 7.43 & 6.76 & 5.24 & 5.18 & 5.45 & 6.46 \\
$\mathrm{Na}_{2} \mathrm{O}$ & 2.50 & 5.05 & 3.77 & 4.45 & 4.23 & 4.77 & 4.13 & 4.56 \\
$\mathrm{~K}_{2} \mathrm{O}$ & 1.77 & 2.76 & 2.50 & 1.84 & 3.03 & 3.06 & 3.47 & 0.80 \\
$\mathrm{TiO}_{2}$ & 1.54 & 1.12 & 1.30 & 1.14 & 1.02 & 1.25 & 0.95 & 1.63 \\
$\mathrm{P}_{2} \mathrm{O}_{5}$ & 0.38 & 0.62 & 0.52 & 0.89 & 0.45 & 0.44 & 0.52 & 0.51 \\
$\mathrm{MnO}$ & 0.15 & 0.15 & 0.14 & 0.16 & 0.11 & 0.14 & 0.16 & 0.13 \\
$\mathrm{LOI}$ & 3.79 & 2.14 & 1.80 & 5.98 & 1.56 & 1.94 & 2.43 & 6.07 \\
& & & & & & & & \\
$\mathrm{Rb}$ & 34 & 50 & 42 & 29 & 53 & 61 & 84 & 12 \\
$\mathrm{Sr}$ & 695 & 991 & 1,117 & 1,175 & 903 & 1,085 & 1,009 & 1,739 \\
$\mathrm{Y}$ & 18 & 22 & 26 & 33 & 22 & 19 & 23 & 31 \\
$\mathrm{Zr}$ & 131 & 164 & 176 & 294 & 205 & 172 & 161 & 154 \\
$\mathrm{Nb}$ & 19 & 19 & 20 & 62 & 14 & 21 & 16 & 27 \\
$\mathrm{Ba}$ & 1,024 & 2,019 & 1,638 & 2,685 & 1,838 & 1,810 & 1,816 & 810 \\
$\mathrm{La}$ & 48 & 59 & 46 & 95 & 67 & 30 & 36 & 32 \\
$\mathrm{Ce}$ & 63 & 120 & 102 & 172 & 79 & 93 & 105 & 97 \\
$\mathrm{Nd}$ & 27 & 47 & 49 & 87 & 49 & 10 & 51 & 29 \\
\hline & & & & & & & &
\end{tabular}

Samples from six intrusions (mostly sills) peripheral to the Crazy Mountains dike swarm were dated by the ${ }^{40} \mathrm{Ar} /{ }^{39} \mathrm{Ar}$ step-heating method. Mineral separates were prepared by standard crushing and sieving techniques, and concentrates were prepared by standard gravimetric (heavy liquid) and magnetic separation techniques. Mineral concentrates were further purified by hand picking to an estimated visual purity of greater than 99.9 percent. Mineral separates were loaded in aluminum foil capsules, sealed in silica vials, and irradiated for 30 hours in the central thimble of the U.S. Geological Survey (USGS) TRIGA reactor in Denver, Colo. Vertical and horizontal gradients of neutron fluence in the irradiated package were monitored by $8-10$ standards distributed along the length of each vial; the geometry of the irradiated package was such that each unknown sample was adjacent to at least one standard. We monitored neutron fluence using hornblende standard MMhb-1 (Samson and Alexander, 1987), which has a K-Ar age of 520.4 $\pm 1.7 \mathrm{Ma}$ (Samson and Alexander, 1987). Production ratios measured on pure $\mathrm{K}_{2} \mathrm{SO}_{4}$ and $\mathrm{CaF}_{2}$ salts irradiated with the samples were used to correct for irradiation-produced ${ }^{40} \mathrm{Ar}$ (from K) and ${ }^{39} \mathrm{Ar}$ (from Ca).

After irradiation, samples were progressively degassed in a double-vacuum resistance furnace in a series of eight to ten 20 -minute-long steps to a maximum temperature of $1,450^{\circ} \mathrm{C}$. After each heating step, we collected the gas and purified it using Zr-Al-Ti getters, and all five argon isotopes were measured with a mass spectrometer operated in the static mode. We calculated apparent ages using decay constants recommended by Steiger and Jäger (1977). We evaluated argon data using age spectra, apparent ${ }^{39} \mathrm{Ar} /{ }^{37} \mathrm{Ar}$ ratios (hornblende separate), and ${ }^{39} \mathrm{Ar} /{ }^{40} \mathrm{Ar}$ versus ${ }^{36} \mathrm{Ar} /{ }^{40} \mathrm{Ar}$ correlation diagrams. The determination of whether the individual apparent ages in an age spectrum yielded a "plateau" was made by applying the criteria of Fleck and others (1977). These criteria define a plateau as comprising two or more contiguous gas fractions that yield apparent ages statistically indistinguishable at the 95-percent confidence level (using the critical-value test as applied by Dalrymple and Lanphere, 1969) and that together constitute greater than 50 percent of the total potassium-derived ${ }^{39} \mathrm{Ar}\left({ }^{39} \mathrm{Ar} \mathrm{K}_{\mathrm{K}}\right)$ released in the step-heating experiment. The plateau age was calculated from a weighted mean, where weighting is by the inverse of the analytical variance (Taylor, 1982). Total gas, plateau, and correlation ages are given at $\pm 2 \sigma$ and include the analytical uncertainty in the determination of the fluence parameter $J$. Complete details for procedures used in the USGS Denver Argon Geochronology Laboratory were presented by Snee (2002).

\section{Petrography}

Compositionally and texturally diverse rhyolite-to-basalt dikes associated with the Big Timber stock are light gray to dark greenish gray, pinkish gray, and dark brown. Most dikes are medium to dark gray and porphyritic, containing combinations of feldspar, quartz, clinopyroxene, amphibole, biotite, and olivine phenocrysts in an aphanitic to fine-grained groundmass. 


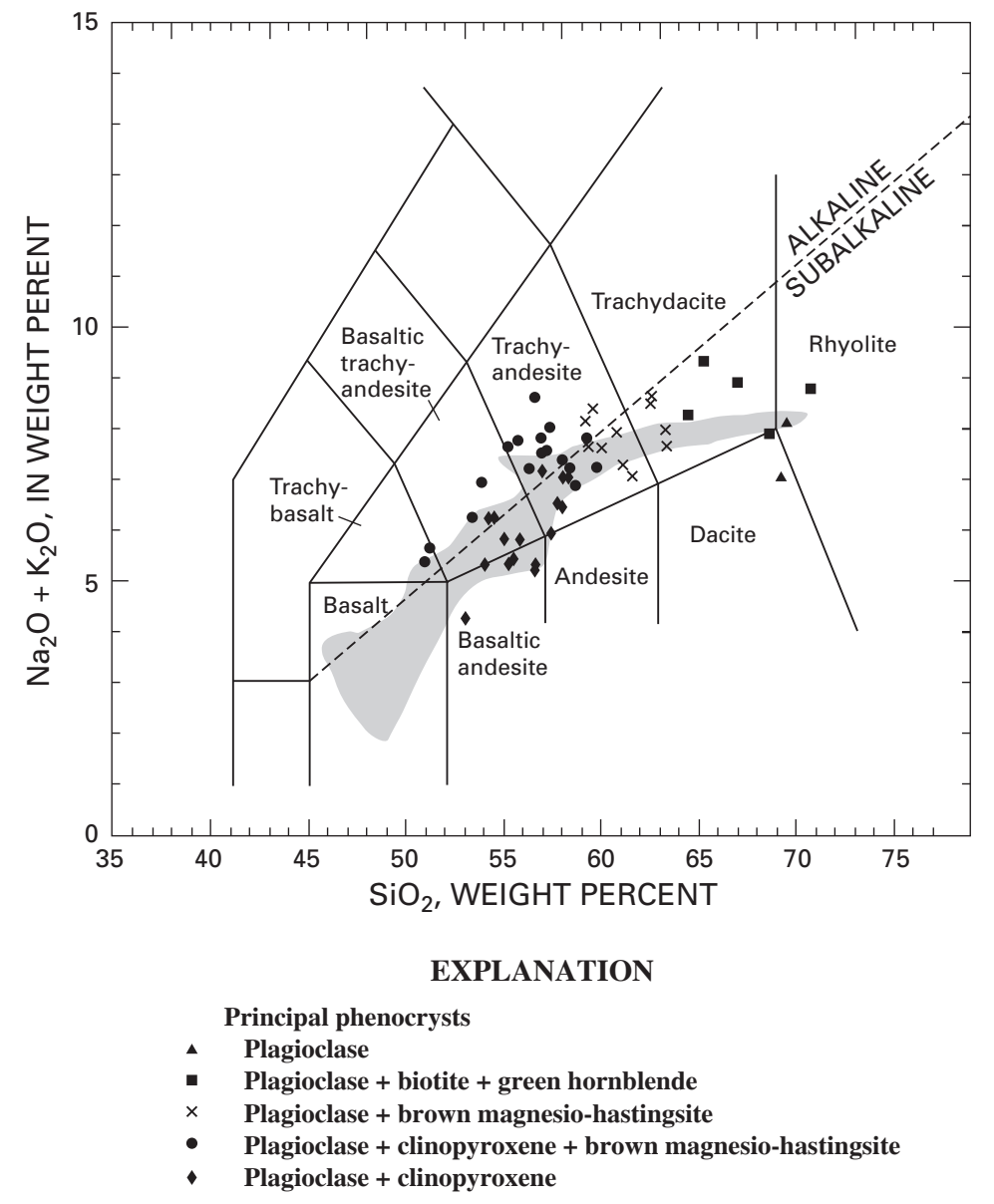

Figure 3. Total alkali-silica variation diagram showing compositions of samples from the Crazy Mountains dike swarm, south-central Montana. International Union of Geological Sciences classification grid (Le Bas and others, 1986) is also shown. Gray-shaded field defined by samples of the Big Timber stock (du Bray and Harlan, 1996).

Phenocryst content ranges from 5 to about 50 percent and averages 20-30 percent. The primary groundmass for most of the dikes was probably glassy; however, no primary glass is present. The groundmass is now a devitrified intergrowth of feldspar, mafic silicate minerals, quartz, opaque oxide minerals, and secondary or alteration minerals. The more detailed petrographic descriptions that follow are based on geochemical groupings. Geochemical data for the 52 analyzed samples form a nearly continuous array but were divided into four groups (rhyolite, trachydacite/dacite, trachyandesite/andesite and basaltic trachyandesite/basaltic andesite, and trachybasalt) of compositionally similar rocks to facilitate synthesis of petrographic data. The descriptions below are synthesized from a number of samples for each of the four composition types and are presented to characterize mineralogic and petrographic variation among dikes of various compositions.

Only two of the sampled dikes (samples 202607 and 202712) are composed of rhyolite (fig. 3). Rhyolite dikes account for about 5 percent of the Crazy Mountains dike swarm; consequently, they are not a major component of the swarm. Petrographic characteristics define two principal types of rhyolite dikes: (1) rapidly cooled or quenched dikes and (2) more slowly cooled, phaneritic dikes, which are petrographically equivalent to the fine- to medium-grained quartz monzodiorite that forms the irregularly shaped intrusion at the core of the Big Timber stock. In addition to the two rhyolite samples, a third sample (202705), whose composition is dacite, is petrographically identical to one of the rhyolite samples (202607). Given the petrographic characteristics of sample 202705, its nearly rhyolite composition, its elevated volatile content, and its highly altered nature, we concluded that the primary composition of this sample may well have been rhyolite; its petrographic features are synthesized with those of sample 202607 in the following description. Similarly, a fourth sample (202503), whose composition is also dacite, is petrographically most similar to the other rhyolite sample (202712). Consequently, petrographic features of sample 202503 are synthesized with those of sample 202712 in the following description. 
The rapidly cooled or quenched rhyolite dikes (samples 202607 and 202705) contain 15-25 percent phenocrysts in an aphanitic, intersertal groundmass composed of a turbid intergrowth of calcite, sericite, quartz, and feldspar. The principal phenocrysts in these rocks are subhedral to euhedral feldspar laths 1-1.5 mm long, most of which are almost entirely replaced by calcite and sericite. These dikes also contain trace amounts of anhedral quartz, opaque oxide minerals, and zircon but do not include mafic silicate phenocrysts. Secondary, subhedral flakes of sericite as much as $1 \mathrm{~mm}$ long constitute about 1 percent of each sample, and secondary opaque oxide minerals form pseudomorphs after titanite.

The phaneritic rhyolite dikes (samples 202712 and 202503) are composed of hypidiomorphic granular, seriate rock that contains varying proportions of plagioclase, quartz, potassium feldspar, biotite, green hornblende, and magnetite; the more mafic of these two samples (202503) also contains clinopyroxene. These dike rocks contain accessory titanite, apatite, and zircon and glomerocrysts of hornblende, biotite, plagioclase, and opaque oxide minerals. Subhedral to euhedral, moderately compositionally zoned plagioclase laths are $0.5-1 \mathrm{~mm}$ long. Anhedral, interstitial quartz grains are $0.5 \mathrm{~mm}$ in diameter. Weakly exsolved, anhedral potassium feldspar grains are interstitial and $0.5-1 \mathrm{~mm}$ in diameter. Straw-yellow to tan, anhedral biotite is interstitial and forms cleavage flakes less than $0.5 \mathrm{~mm}$ in diameter. Pale-green, anhedral to subhedral amphibole laths are $0.5 \mathrm{~mm}$ long. Anhedral grains of pale-green clinopyroxene are $0.1-0.5 \mathrm{~mm}$ in diameter.

Seven dike samples (in addition to samples 202705 and 202712, which were included in the petrographic syntheses of the two types of rhyolite dikes previously described) are composed of trachydacite/dacite. As such, about 15 percent of the Crazy Mountains dike swarm is composed of dikes that have trachydacite/dacite compositions. Among these seven samples, we identified two groups, each having distinctive petrographic features; these two sample groups also define unique compositional fields (fig. 3).

The first group (three solid squares plotted wholly within the trachydacite field, fig. 3) of dacitic dikes (samples 202602, 202714, and 202726) is characterized by biotite and (or) green magnesio-hornblende (du Bray and Harlan, 1996) as the predominant mafic silicate mineral. These dikes contain 10-30 percent phenocrysts in a turbid, aphanitic, intersertal groundmass composed of feldspar, quartz, opaque oxide minerals, hornblende, and secondary and (or) alteration minerals, including chlorite and clay. Subhedral to euhedral plagioclase is the predominant phenocryst phase in these dikes and forms albite-twinned and moderately zoned laths 1-4 mm long. In some samples, plagioclase was partly replaced by calcite, sericite, and clay minerals. Yellowish-green to pale-green magnesio-hornblende phenocrysts, some of which were partly replaced by chlorite or biotite, form anhedral to subhedral grains that are $0.5-1 \mathrm{~mm}$ long. Subhedral grains of tan to red-brown biotite are 1-3 $\mathrm{mm}$ in diameter. Opaque oxide phenocrysts form anhedral to subhedral grains $0.1-0.5$ $\mathrm{mm}$ in diameter. These dike samples contain accessory apatite and zircon, and some contain glomerocrysts of plagioclase, hornblende, biotite, and opaque oxide minerals. Dike sample 202714 has the lowest $\mathrm{SiO}_{2}$ and total alkali contents of these three trachydacites and, in terms of its petrography, is transitional between the two groups of trachydacite dikes: it has biotite as its principal mafic silicate mineral but also contains distinctive brown amphibole. The major-oxide composition of this sample is similarly transitional between the two compositionally distinct types of trachydacite, shown by solid squares and the symbol $\times$ in figure 3 .

The second group (four solid $\times$ symbols plotted in the trachydacite field, fig. 3) of dacitic dikes (samples 202306, 202310, 202622, and 202734) contains brown or brownishgreen magnesio-hastingsite (du Bray and Harlan, 1996) as the predominant mafic silicate mineral. These dikes contain 5-30 percent phenocrysts in a turbid, aphanitic, intersertal groundmass composed of feldspar (in part replaced by calcite), opaque oxide minerals, and lesser amounts of green hornblende. The groundmass was replaced, in part, by combinations of secondary chlorite, calcite, and epidote. Subhedral to euhedral plagioclase is the predominant phenocryst phase in these dikes and forms albite-twinned and moderately zoned laths 1-3 mm long. In some samples, plagioclase was completely replaced by clay minerals. Magnesio-hastingsite phenocrysts form euhedral laths and equant grains that range in length or diameter from 0.5 to $1.5 \mathrm{~mm}$. Some of these amphibole grains were partly to completely replaced by chlorite. Opaque oxide phenocrysts form anhedral to subhedral grains $0.2-0.5 \mathrm{~mm}$ in diameter. These dikes contain accessory quartz, apatite, titanite, and zircon and glomerocrysts of feldspar, magnesio-hastingsite, and opaque oxide minerals.

Thirty-nine of the samples (about 75 percent of the dikes) are composed of trachyandesite/andesite and basaltic trachyandesite/basaltic andesite. These trachyandesitic dikes form two petrographically distinct groups; one group (24 samples) is characterized by brown magnesio-hastingsite phenocrysts (du Bray and Harlan, 1996) and the other group (15 samples) contains clinopyroxene as the sole mafic silicate phenocryst. The two groups, respectively termed "magnesiohastingsite trachyandesite" dikes and "clinopyroxene trachyandesite" dikes, are described in the following paragraphs.

The magnesio-hastingsite (du Bray and Harlan, 1996) trachyandesite dikes contain 5-30 percent phenocrysts (although several dikes are phaneritic and several are aphanitic) in a turbid, aphanitic, intersertal groundmass composed of feldspar (in part replaced by calcite), opaque oxide minerals, and lesser amounts of green hornblende. The groundmass has been replaced, in part, by combinations of secondary chlorite, calcite, and epidote. Subhedral to euhedral plagioclase is the predominant phenocryst phase in most of these dikes and forms albite-twinned and moderately zoned laths 1-3 mm long. In some samples, plagioclase has been completely replaced by clay minerals. Magnesio-hastingsite phenocrysts are the predominant phenocrysts in some dikes, forming euhedral laths and more equant grains that range in length or diameter from 0.5 to $1.5 \mathrm{~mm}$. Some of these amphibole grains are partly 
to completely replaced by chlorite. Most of these dikes (solid circles, fig. 3) also contain colorless to pale-tan, lath-shaped, anhedral to subhedral clinopyroxene phenocrysts that are 0.5-2 mm long; seven magnesio-hastingsite trachyandesite dikes that lack clinopyroxene are plotted in the trachyandesite field in figure 3 (symbol $\times$ ). Opaque oxide phenocrysts form anhedral to subhedral grains $0.2-0.5 \mathrm{~mm}$ in diameter. These dikes contain accessory quartz, apatite, titanite, and zircon and glomerocrysts of feldspar, magnesio-hastingsite, and opaque oxide minerals.

The clinopyroxene trachyandesite dikes include both crystal-rich and crystal-poor varieties. The crystal-poor dikes $(n=8)$ average 8 percent phenocrysts, whereas the crystalrich dikes $(n=7)$ contain about 35 percent phenocrysts. The two varieties are otherwise similar and include an aphanitic, intersertal groundmass composed of feldspar (in part replaced by calcite), opaque oxide minerals, and chlorite and lesser amounts of clinopyroxene and devitrified glass. Plagioclase is the predominant phenocryst phase in these dikes and forms subhedral to euhedral albite-twinned and moderately zoned laths $1-5 \mathrm{~mm}$ long. Subhedral clinopyroxene phenocrysts form very pale tan, lath-shaped to granular grains that range in length or diameter from 0.5 to $3 \mathrm{~mm}$. Opaque oxide phenocrysts form anhedral to subhedral grains $0.2-0.5 \mathrm{~mm}$ in diameter. These dikes contain accessory apatite and glomerocrysts of feldspar, clinopyroxene, and opaque oxide minerals. Some dikes contain chlorite that appears to pseudomorph completely replaced olivine crystals. Secondary calcite and chlorite are abundant in some dikes, whereas mixtures of chlorite and clay seem to have replaced primary interstitial glass in others.

Similar to the rhyolite dikes, trachybasalt dikes are rare and account for less than 5 percent of all dikes in the swarm. Only two samples (202620 and 202725) are composed of basalt (fig. 3). The two basalt dike samples have substantially different petrographic characteristics even though their chemical compositions (table 1; fig. 3) are similar. Sample 202725 contains about 25 percent phenocrysts in an aphanitic, intersertal groundmass composed of plagioclase, hornblende, chlorite, and biotite. Green, subhedral grains of calcic augite (du Bray and Harlan, 1996) $2.5 \mathrm{~mm}$ in diameter are the predominant phenocryst type in this sample. Other phenocryst phases include plagioclase and magnesio-hastingstite. Plagioclase forms euhedral, albite-twinned and weakly zoned laths about $3 \mathrm{~mm}$ long. Magnesio-hastingstite forms euhedral brown laths that are about $1.5 \mathrm{~mm}$ long. This type of dike contains accessory apatite and relatively abundant secondary chlorite. Minor opaque oxide minerals form anhedral grains that are $0.5 \mathrm{~mm}$ in diameter. The other type of basalt dike (sample 202712) contains only 10 percent phenocrysts, also in an aphanitic, intersertal matrix that is composed of plagioclase, magnesio-hastingsite, and opaque oxide minerals. Subequal amounts of olivine and magnesio-hastingsite form most of the phenocrysts in this type of dike. Olivine is colorless and forms subhedral grains as much as $2 \mathrm{~mm}$ in diameter. Magnesiohastingsite forms brown, subhedral to euhedral laths as much as $3 \mathrm{~mm}$ long. Minor plagioclase, in part replaced by calcite, forms zoned laths that are as much as $3 \mathrm{~mm}$ long. Some olivine appears to have been replaced by chlorite. This type of dike also contains minor amounts of opaque oxide minerals that form anhedral phenocrysts less than $0.2 \mathrm{~mm}$ in diameter.

\section{Geochronology}

Five of the six samples dated by the ${ }^{40} \mathrm{Ar} /{ }^{39} \mathrm{Ar}$ step-heating method are splits of mineral separates that were previously dated by the K-Ar method (Harlan, 1986; Harlan and others, 1988). The dates reported here are for samples of alkaline sills, a dike, and a stock in the northern part of the Crazy Mountains. In addition, we report a new ${ }^{40} \mathrm{Ar} /{ }^{39} \mathrm{Ar}$ date for the strongly alkaline Ibex Mountain sill, west of the Big Timber stock. A K-Ar date for this sill was also reported by Harlan and others (1988), but the sample dated in the present study was newly collected subsequent to the completion of that study. Sample descriptions were presented by Harlan (1986) and Harlan and others (1988), and sample localities are shown in figure $1 A$ of this report. Results of the ${ }^{40} \mathrm{Ar} /{ }^{39} \mathrm{Ar}$ dating are presented as age spectra in figure 4 , and complete analytical data are presented in table 2 .

Sample 82VP-2 was collected from a trachyte sill exposed along the eastern flank of the Robinson anticline intrusive complex (fig. 1A, locality 1 ). Hornblende from the sill previously yielded a K-Ar date of $48.8 \pm 4.6 \mathrm{Ma}(1 \sigma)$ (Harlan and others, 1988). $\mathrm{An}^{40} \mathrm{Ar} /{ }^{39} \mathrm{Ar}$ analysis of the same mineral concentrate gave a somewhat discordant age spectrum with a total gas age of $50.84 \pm 0.28 \mathrm{Ma}(2 \sigma)$ (table 2$)$. The spectrum is somewhat $\mathrm{U}$-shaped, older ages being indicated by data for the lower temperature steps, but yields a fairly flat profile over about 90 percent of the ${ }^{39} \mathrm{Ar}_{\mathrm{K}}$ released (fig. $4)$. The sample did not yield a plateau according to the strict criteria of Fleck and others (1977), but we consider the best age estimate for the sample to be defined by the intermediate temperature steps $\left(1,100-1,350^{\circ} \mathrm{C}\right)$, which give a reasonably flat release pattern and a weighted mean age of $50.61 \pm 0.14$ $\mathrm{Ma}(2 \sigma)$ (table 3$)$. We interpret this date to best represent the emplacement age of the trachyte sill. The age is analytically indistinguishable from the previously determined K-Ar date but is analytically much more precise.

Five biotite separates from strongly alkaline intrusions, which range from mafic nepheline syenite to nepheline syenite, were dated by the ${ }^{40} \mathrm{Ar}{ }^{39} \mathrm{Ar}$ method. These include the sill(?) at Ibex Mountain, just west of the subalkaline Big Timber stock (fig. $1 A$, locality 2), sills of the Robinson anticline intrusive complex (fig. $1 A$, localities 3 and 4), and the Comb Creek stock and an associated radial dike (fig. 1A, localities 5 and 6). Previous K-Ar dating of mineral concentrates from these intrusions gave ages ranging from $48.0 \pm 1.9$ $(1 \sigma)$ to 52.6 $\pm 2.0(1 \sigma)$ (table 3) (Harlan, 1986; Harlan and others, 1988). Interpretation of ${ }^{40} \mathrm{Ar} /{ }^{39} \mathrm{Ar}$ results for these samples is reasonably straightforward. Although individual age spectra show minor complications in low- or hightemperature steps (fig. 4), all samples yielded well-defined, 

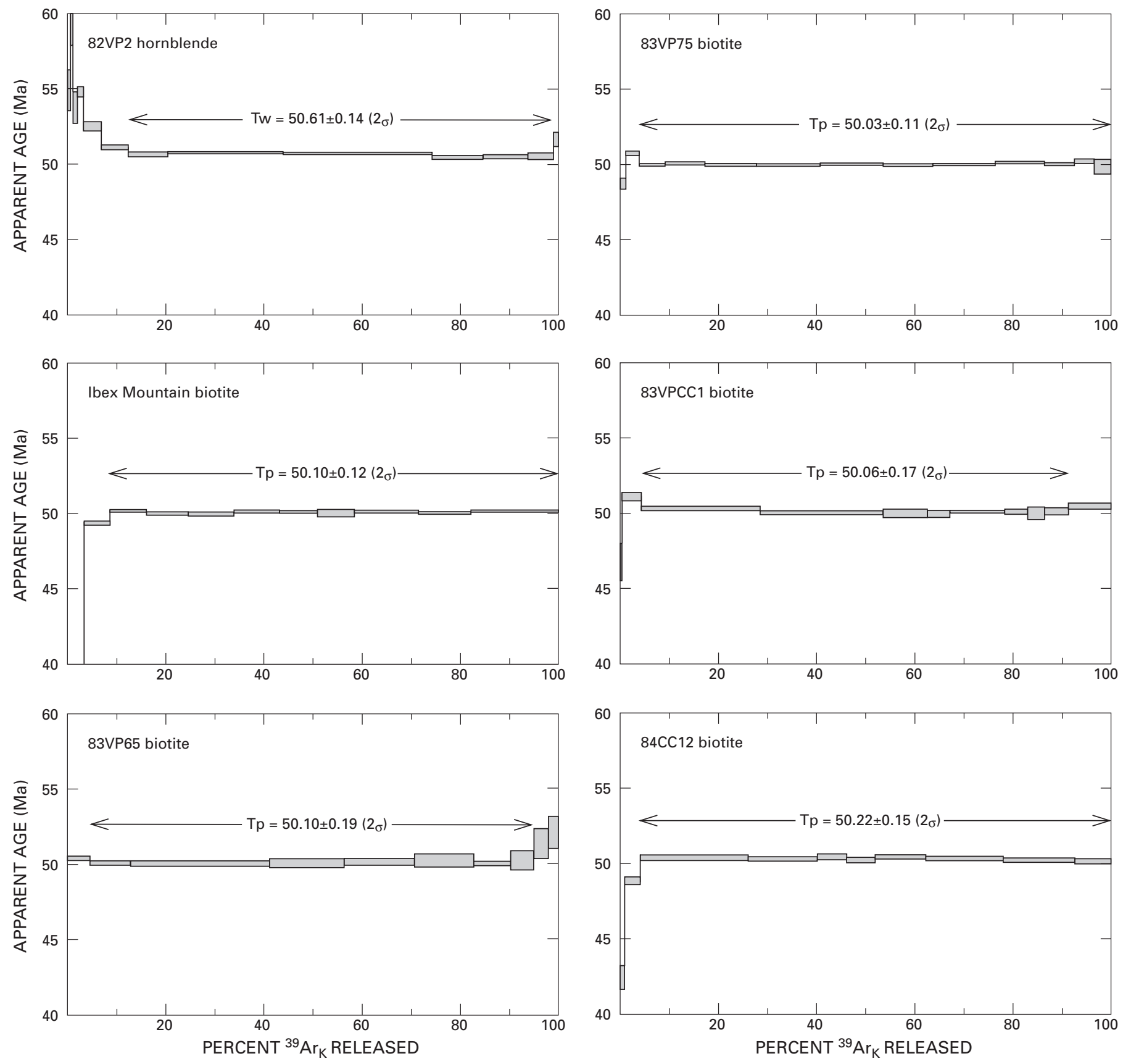

Figure 4. Graphs showing ${ }^{40} \mathrm{Ar} /{ }^{39} \mathrm{Ar}$ age spectra for hornblende and biotite separates from alkaline intrusive rocks in the Crazy Mountains, south-central Montana. Analytical error in the apparent age for each temperature step in the age spectra is represented by the height of the shaded rectangle; the proportion of ${ }^{39} \mathrm{Ar}_{\mathrm{K}}$ released in step-heating experiments is represented by the length of the shaded rectangle. Arrows show steps in the age spectra used to define the plateau (Tp) or weighted mean (Tw) dates, as described in the text. Analytical error in the mean age is given at $\pm 2 \sigma$. 
Table 2. Data for ${ }^{40} \mathrm{Ar} /{ }^{39} \mathrm{Ar}$ step heating of samples of alkaline sills in the Crazy Mountains, south-central Montana.

$\left[\right.$ Note: ${ }^{40} \mathrm{Ar}_{\mathrm{a}}$ is measured atmospheric argon used for mass-discrimination at time of analysis; ${ }^{40} \mathrm{Ar}_{\mathrm{R}}$ is radiogenic ${ }^{40} \mathrm{Ar}$ in volts signal; ${ }^{39} \mathrm{Ar}_{\mathrm{K}}$ is potassium-derived ${ }^{39} \mathrm{Ar}$ in volts signal; ${ }^{40} \mathrm{Ar}_{\mathrm{R}} /{ }^{39} \mathrm{Ar}_{\mathrm{K}}$ is the ratio of ${ }^{40} \mathrm{Ar}_{\mathrm{R}}$ to ${ }^{39} \mathrm{Ar}_{\mathrm{K}}$ after correction for mass-discrimination and interfering isotopes; ${ }^{39} \mathrm{Ar} /{ }^{37} \mathrm{Ar}=$ ratio of ${ }^{39} \mathrm{Ar}_{\mathrm{K}}$ to ${ }^{37} \mathrm{Ar}_{\mathrm{Ca}}$ (this value can be converted to the approximate $\mathrm{K} / \mathrm{Ca}$ by multiplying by 0.52 ); $\%{ }^{40} \mathrm{Ar}_{\mathrm{K}}$ and $\%{ }^{39} \mathrm{Ar}$ are the percentage of radiogenic ${ }^{40} \mathrm{Ar}$ and percentage of total ${ }^{39} \mathrm{Ar}$ released in each temperature step. Conversion of volts signal to moles Ar can be made using a conversion factor of $1.252 \times 10^{-13}$ moles argon per volt of signal. Steps denoted by bold font are those used in calculation of the plateau or weighted mean dates as described in the text. Analytical details are available in Snee (2002)]

\begin{tabular}{|c|c|c|c|c|c|c|c|}
\hline $\begin{array}{c}\text { Temp } \\
\left({ }^{\circ} \mathrm{C}\right)\end{array}$ & ${ }^{40} \mathrm{Ar}_{\mathrm{R}}$ & ${ }^{39} \mathrm{Ar}_{\mathrm{K}}$ & ${ }^{40} \mathrm{Ar}_{\mathrm{R}} /{ }^{39} \mathrm{Ar}_{\mathrm{K}}$ & ${ }^{39} \mathrm{Ar} /{ }^{37} \mathrm{Ar}$ & $\%{ }^{40} \mathrm{Ar}_{\mathrm{R}}$ & $\%{ }^{39} \mathrm{Ar}$ & $\begin{array}{c}\text { Apparent age } \\
(\mathrm{Ma} \pm 1 \sigma)\end{array}$ \\
\hline \multicolumn{8}{|c|}{ Sample 82VP2: Hornblende, trachyte, sill; $70.9 \mathrm{mg} ;{ }^{40} \mathrm{Ar} /{ }^{36} \mathrm{Ar}=298.9 ; \mathrm{J}$-value $=0.00769 \pm 0.1 \%(1 \sigma)$} \\
\hline 700 & 0.12645 & 0.03153 & 4.011 & 2.62 & 21.6 & 0.6 & $54.87 \pm 1.37$ \\
\hline 800 & 0.11665 & 0.02694 & 4.329 & 1.56 & 20.2 & 0.5 & $59.15 \pm 1.29$ \\
\hline 900 & 0.22156 & 0.05643 & 3.926 & 1.07 & 62.3 & 1.0 & $53.73 \pm 1.05$ \\
\hline 975 & 0.27472 & 0.06863 & 4.003 & 0.84 & 74.7 & 1.2 & $54.76 \pm 0.35$ \\
\hline 1,050 & 0.78274 & 0.20420 & 3.833 & 0.43 & 75.7 & 3.6 & $52.47 \pm 0.29$ \\
\hline 1,075 & 1.1540 & 0.30934 & 3.730 & 0.37 & 86.1 & 5.4 & $51.09 \pm 0.15$ \\
\hline 1,100 & 1.73822 & 0.47043 & 3.695 & 0.36 & 91.1 & 8.3 & $50.61 \pm 0.15$ \\
\hline 1,125 & 4.9527 & 1.3374 & 3.703 & 0.35 & 93.7 & 23.5 & $50.72 \pm 0.08$ \\
\hline 1,150 & 6.4046 & 1.7318 & 3.698 & 0.35 & 94.6 & 30.4 & $50.67 \pm 0.08$ \\
\hline 1,200 & 2.1640 & 0.58862 & 3.676 & 0.34 & 92.5 & 10.3 & $50.36 \pm 0.13$ \\
\hline 1,250 & 1.9220 & 0.52223 & 3.680 & 0.29 & 93.8 & 9.2 & $50.41 \pm 0.14$ \\
\hline 1,350 & 1.1035 & 0.29962 & 3.683 & 0.27 & 92.3 & 5.3 & $50.45 \pm 0.21$ \\
\hline 1,450 & 0.20734 & 0.05506 & 3.766 & 0.28 & 82.5 & 1.0 & $51.56 \pm 0.47$ \\
\hline Total gas & & & 3.712 & & & & $50.84 \pm 0.14$ \\
\hline \multicolumn{8}{|c|}{ Sample from Ibex Mountain: Biotite, mafic nepheline syenite, sill, $50.9 \mathrm{mg} ;{ }^{40} \mathrm{Ar} /{ }^{36} \mathrm{Ar} a \mathrm{a}=298.9 ; \mathrm{J}$-value $=0.007781 \pm 0.1 \%(1 \sigma)$} \\
\hline 600 & 0.05104 & 0.04121 & 1.238 & 20.70 & 0.7 & 0.7 & $17.30 \pm 0.99$ \\
\hline 700 & 0.42849 & 0.16230 & 2.640 & 53.49 & 56.6 & 2.6 & $36.68 \pm 0.17$ \\
\hline 750 & 1.14790 & 0.32306 & 3.564 & 102.33 & 70.8 & 5.2 & $49.35 \pm 0.13$ \\
\hline 800 & 1.65660 & 0.45697 & 3.265 & 137.22 & 86.0 & 7.4 & $50.18 \pm 0.08$ \\
\hline 850 & 1.93705 & 0.53609 & 3.613 & 183.78 & 87.9 & 8.7 & $50.02 \pm 0.09$ \\
\hline 900 & 2.05721 & 0.56998 & 3.609 & 250.85 & 89.1 & 9.2 & $49.96 \pm 0.14$ \\
\hline 950 & 2.07748 & 0.57350 & 3.622 & 174.92 & 90.3 & 9.3 & $50.14 \pm 0.10$ \\
\hline 1,000 & 1.74716 & 0.48279 & 3.619 & 137.74 & 88.7 & 7.8 & $50.10 \pm 0.08$ \\
\hline 1,050 & 1.66418 & 0.46037 & 3.615 & 104.29 & 90.3 & 7.5 & $50.04 \pm 0.24$ \\
\hline 1,100 & 2.90917 & 0.80330 & 3.622 & 71.88 & 86.7 & 13.0 & $50.13 \pm 0.08$ \\
\hline 1,150 & 2.38796 & 0.66073 & 3.614 & 53.21 & 82.7 & 10.7 & $50.03 \pm 0.08$ \\
\hline 1,350 & 3.98206 & 1.09858 & 3.625 & 15.99 & 79.7 & 17.8 & $50.18 \pm 0.08$ \\
\hline Total gas & & & 3.574 & & & & $49.49 \pm 0.12$ \\
\hline \multicolumn{8}{|c|}{ Sample 83VP65: Biotite; mafic nepheline syenite, sill; $59.7 \mathrm{mg}$; measured ${ }^{40} \mathrm{Ar} /{ }^{36} \mathrm{Ar}_{\mathrm{a}}=298.9 ; \mathrm{J}$-value $=0.00623 \pm 0.1 \%(1 \sigma)$} \\
\hline 600 & 1.05374 & 0.23180 & 4.546 & 99.29 & 58.1 & 4.5 & $50.38 \pm 0.14$ \\
\hline 700 & 1.91901 & 0.42471 & 4.518 & 161.74 & 78.0 & 8.3 & $50.08 \pm 0.16$ \\
\hline 800 & 6.54108 & 1.44775 & 4.518 & 352.04 & 93.4 & 28.3 & $50.08 \pm 0.19$ \\
\hline 850 & 3.51108 & 0.77686 & 4.520 & 745.20 & 93.5 & 15.2 & $50.09 \pm 0.33$ \\
\hline 900 & 3.32483 & 0.73430 & 4.528 & 340.31 & 93.2 & 14.4 & $50.18 \pm 0.26$ \\
\hline 950 & 2.78227 & 0.61316 & 4.538 & 308.36 & 92.2 & 12.0 & $50.29 \pm 0.42$ \\
\hline 1,000 & 1.72834 & 0.38260 & 4.517 & 160.59 & 80.4 & 7.5 & $50.07 \pm 0.14$ \\
\hline 1,050 & 1.09643 & 0.24175 & 4.535 & 78.10 & 65.3 & 4.7 & $50.27 \pm 0.65$ \\
\hline 1,100 & 0.70177 & 0.15125 & 4.640 & 37.65 & 51.0 & 3.0 & $51.41 \pm 1.00$ \\
\hline 1,300 & 0.48709 & 0.10349 & 4.707 & 5.06 & 41.5 & 2.0 & $52.14 \pm 1.07$ \\
\hline Total gas & & & 4.532 & & & & $50.22 \pm 1.07$ \\
\hline
\end{tabular}


Table 2. Data for ${ }^{40} \mathrm{Ar} /{ }^{39} \mathrm{Ar}$ step heating of samples of alkaline sills in the Crazy Mountains, south-central Montana. -Continued

\begin{tabular}{|c|c|c|c|c|c|c|c|}
\hline $\begin{array}{c}\text { Temp } \\
\left({ }^{\circ} \mathrm{C}\right)\end{array}$ & ${ }^{40} \mathrm{Ar}_{\mathrm{R}}$ & ${ }^{39} \mathrm{Ar}_{\mathrm{K}}$ & ${ }^{40} \mathrm{Ar}_{\mathrm{R}} /{ }^{39} \mathrm{Ar}_{\mathrm{K}}$ & ${ }^{39} \mathrm{Ar} /{ }^{37} \mathrm{Ar}$ & $\%{ }^{40} \mathrm{Ar}_{\mathrm{R}}$ & $\%{ }^{39} \mathrm{Ar}$ & $\begin{array}{c}\text { Apparent age } \\
(\mathrm{Ma} \pm 1 \sigma)\end{array}$ \\
\hline \multicolumn{8}{|c|}{ Sample 83VP75: Biotite, mafic nepheline syenite, sill; $70.9 \mathrm{mg} ;{ }^{40} \mathrm{Ar} /{ }^{36} \mathrm{Ar}_{\mathrm{a}}=298.9 ; \mathrm{J}$-value $=0.007825 \pm 0.1 \%(1 \sigma)$} \\
\hline 600 & 0.35848 & 0.10247 & 3.498 & 51.92 & 48.4 & 1.1 & $48.72 \pm 0.37$ \\
\hline 700 & 0.97747 & 0.26818 & 3.645 & 93.60 & 87.9 & 2.8 & $50.73 \pm 0.15$ \\
\hline 750 & 1.84141 & 0.51303 & 3.589 & 128.80 & 84.9 & 5.3 & $49.97 \pm 0.08$ \\
\hline 800 & 2.83212 & 0.78754 & 3.596 & 190.88 & 92.0 & 14.5 & $50.06 \pm 0.11$ \\
\hline 850 & 3.64399 & 1.01482 & 3.594 & 333.53 & 94.8 & 10.5 & $49.99 \pm 0.09$ \\
\hline 900 & 4.53069 & 1.23591 & 3.589 & 293.40 & 94.7 & 13.0 & $49.97 \pm 0.08$ \\
\hline 950 & 4.44170 & 1.23591 & 3.594 & 187.92 & 93.9 & 12.8 & $50.03 \pm 0.08$ \\
\hline 1,000 & 3.54210 & 0.98650 & 3.591 & 122.61 & 91.8 & 10.2 & $49.99 \pm 0.09$ \\
\hline 1,050 & 4.39253 & 1.22284 & 3.592 & 115.85 & 86.3 & 12.6 & $50.01 \pm 0.08$ \\
\hline 1,100 & 3.49982 & 0.97170 & 3.602 & 73.45 & 77.4 & 10.0 & $50.14 \pm 0.08$ \\
\hline 1,150 & 2.09815 & 0.58376 & 3.594 & 32.27 & 69.0 & 6.0 & $50.04 \pm 0.11$ \\
\hline 1200 & 1.38955 & 0.38493 & 3.610 & 14.50 & 52.9 & 4.0 & $50.25 \pm 0.14$ \\
\hline 1350 & 1.22904 & 0.34308 & 3.591 & 3.85 & 57.8 & 3.5 & $49.87 \pm 0.49$ \\
\hline Total gas & & & 3.594 & & & & $50.03 \pm 0.10$ \\
\hline \multicolumn{8}{|c|}{ Sample 83VPCC1: Biotite, mafic nepheline syenite, dike, $61.3 \mathrm{mg} ;{ }^{40} \mathrm{Ar} /{ }^{36} \mathrm{Ar}_{\mathrm{a}}=298.9 ; \mathrm{J}$-value $=0.006138 \pm 0.1 \%(1 \sigma)$} \\
\hline 600 & 0.08828 & 0.02069 & 4.266 & 15.21 & 7.7 & 0.4 & $46.63 \pm 1.22$ \\
\hline 700 & 1.00596 & 0.21530 & 4.672 & 35.74 & 65.4 & 4.0 & $51.01 \pm 0.30$ \\
\hline 800 & 5.94678 & 1.29290 & 4.600 & 78.82 & 88.4 & 24.0 & $50.23 \pm 0.14$ \\
\hline 900 & 6.14365 & 1.34352 & 4.573 & 116.17 & 92.0 & 25.0 & $49.94 \pm 0.14$ \\
\hline 950 & 3.31741 & 0.72587 & 4.570 & 50.47 & 88.8 & 13.5 & $49.91 \pm 0.29$ \\
\hline 1,000 & 2.68422 & 0.58519 & 4.587 & 34.54 & 86.2 & 10.9 & $50.09 \pm 0.14$ \\
\hline 1,025 & 1.21498 & 0.26520 & 4.581 & 23.58 & 80.1 & 4.9 & $50.03 \pm 0.20$ \\
\hline 1,050 & 0.83467 & 0.18252 & 4.573 & 14.05 & 77.5 & 3.4 & $49.94 \pm 0.43$ \\
\hline 1,100 & 1.17611 & 0.25662 & 4.583 & 10.11 & 77.6 & 4.8 & $50.05 \pm 0.22$ \\
\hline 1,250 & 2.26306 & 0.48965 & 4.622 & 2.55 & 70.5 & 9.1 & $50.46 \pm 0.16$ \\
\hline Total gas & & & 4.589 & & & & $50.11 \pm 0.18$ \\
\hline \multicolumn{8}{|c|}{ Sample 84CC12: Biotite, mafic nepheline syenite, stock, $53.2 \mathrm{mg} ;{ }^{40} \mathrm{Ar} /{ }^{36} \mathrm{Ar}_{\mathrm{a}}=298.9 ; \mathrm{J}$-value $=0.006151 \pm 0.1 \%(1 \sigma)$} \\
\hline 600 & 0.18041 & 0.04671 & 3.862 & 37.26 & 35.6 & 0.9 & $42.35 \pm 0.78$ \\
\hline 700 & 0.74269 & 0.16672 & 4.455 & 113.97 & 52.8 & 3.2 & $48.76 \pm 0.25$ \\
\hline 800 & 5.20549 & 1.13237 & 4.597 & 322.98 & 94.3 & 22.0 & $50.30 \pm 0.20$ \\
\hline 850 & 3.35254 & 0.73051 & 4.589 & 385.09 & 96.3 & 14.2 & $50.22 \pm 0.14$ \\
\hline 900 & 1.41193 & 0.30669 & 4.604 & 268.53 & 94.5 & 5.9 & $50.38 \pm 0.19$ \\
\hline 950 & 1.36432 & 0.29800 & 4.578 & 131.95 & 89.4 & 5.8 & $50.10 \pm 0.19$ \\
\hline 1,000 & 2.44198 & 0.53064 & 4.602 & 143.76 & 93.6 & 10.3 & $50.36 \pm 0.15$ \\
\hline 1,050 & 3.73626 & 0.81358 & 4.592 & 138.51 & 95.7 & 15.8 & $50.25 \pm 0.14$ \\
\hline 1,100 & 3.45184 & 0.75335 & 4.582 & 100.21 & 96.1 & 14.6 & $50.14 \pm 0.14$ \\
\hline 1,250 & 1.72665 & 0.37730 & 4.576 & 4.75 & 94.7 & 7.3 & $50.08 \pm 0.16$ \\
\hline Total gas & & & 4.580 & & & & $50.12 \pm 0.16$ \\
\hline
\end{tabular}


Table 3. Summary of isotopic dating results for alkaline sills in the northern Crazy Mountains, south-central Montana.

[Tp, plateau date; Tw, weighted mean date, for which the strict plateau criteria have not been met, as described in text. Analytical error associated with the $\mathrm{K}$-Ar dates is $\pm 1 \sigma$; the error in the ${ }^{40} \mathrm{Ar} /{ }^{39} \mathrm{Ar}$ dates is given at $\pm 2 \sigma$. All ${ }^{40} \mathrm{Ar} /{ }^{39} \mathrm{Ar}$ dates are from mineral separates used in the original $\mathrm{K}$-Ar dating, with the exception of the sample from the Ibex Mountain sill. For this intrusion, a new sample was collected, processed, and dated. K-Ar dates were previously reported by Harlan (1986) and Harlan and others (1988)]

\begin{tabular}{|c|c|c|c|c|c|c|c|c|}
\hline $\begin{array}{c}\text { Sample } \\
\text { locality } \\
\text { (fig. 1) }\end{array}$ & Sample No. & Locality & $\begin{array}{c}\text { Latitude } \\
\left({ }^{\circ} \mathrm{N} .\right)\end{array}$ & $\begin{array}{c}\text { Longitude } \\
\text { ('W.) }\end{array}$ & Rock type & $\begin{array}{c}\text { Material } \\
\text { dated }\end{array}$ & $\begin{array}{c}\text { K-Ar date } \\
\text { (Ma) }\end{array}$ & $\begin{array}{c}{ }^{40} \mathrm{Ar} /{ }^{39} \mathrm{Ar} \text { date } \\
\text { (Ma) }\end{array}$ \\
\hline 1 & $82 \mathrm{VP} 2$ & Robinson anticline & 46.2023 & 110.4592 & Trachyte sill & Hornblende & $48.8 \pm 4.6$ & $\mathrm{Tw}=50.61 \pm 0.14$ \\
\hline 2 & Ibex Mountain & Ibex Mountain & 46.9943 & 110.4479 & $\begin{array}{l}\text { Mafic nepheline } \\
\text { syenite sill(?) }\end{array}$ & Biotite & $50.5 \pm 0.6$ & $\mathrm{Tp}=50.10 \pm 0.12$ \\
\hline 3 & 83VP65 & Robinson anticline & 46.1873 & 110.4918 & $\begin{array}{l}\text { Mafic nepheline } \\
\text { syenite sill }\end{array}$ & Biotite & $50.6 \pm 1.9$ & $\mathrm{Tp}=50.10 \pm 0.19$ \\
\hline 4 & 83VP75 & Robinson anticline & 46.1875 & 110.4637 & $\begin{array}{l}\text { Mafic nepheline } \\
\text { syenite sill }\end{array}$ & Biotite & $49.3 \pm 1.9$ & $\mathrm{Tp}=50.03 \pm 0.11$ \\
\hline 5 & 83VPCC1 & Comb Creek stock & 46.2984 & 110.4453 & $\begin{array}{l}\text { Mafic nepheline } \\
\text { syenite dike }\end{array}$ & Biotite & $52.6 \pm 2.0$ & $\mathrm{Tp}=50.06 \pm 0.17$ \\
\hline 6 & $84 \mathrm{CC} 12$ & Comb Creek stock & 46.307 & 110.499 & $\begin{array}{l}\text { Nepheline syenite } \\
\text { stock }\end{array}$ & Biotite & $48.0 \pm 1.9$ & $\mathrm{Tp}=50.22 \pm 0.15$ \\
\hline
\end{tabular}

plateau-like segments over about 90 percent of the ${ }^{39} \mathrm{Ar}_{\mathrm{K}}$ released in the step-heating experiments. Plateau dates are tightly clustered and range from 50.03 to $50.22 \mathrm{Ma}$, while $2 \sigma$ errors range from \pm 0.11 to $0.19 \mathrm{Ma}$ (fig. 4 ; table 3 ). Because most of the samples are of fairly small hypabyssal intrusions that probably cooled very quickly, we interpret these biotite dates to represent the best estimate of the emplacement age of the strongly alkaline sills, dikes, and the Comb Creek stock. These data indicate that the strongly alkaline intrusive rocks were emplaced during a fairly restricted interval of time at about 50.10 Ma.

Results of the ${ }^{40} \mathrm{Ar} /{ }^{39} \mathrm{Ar}$ step-heating experiments are summarized in table 3 along with preferred ages based on interpretation of isotopic analyses. The ${ }^{40} \mathrm{Ar} /{ }^{39} \mathrm{Ar}$ dates presented here yield ages that are consistent with previously determined $\mathrm{K}-\mathrm{Ar}$ dates but are analytically much more precise. The ${ }^{40} \mathrm{Ar} /{ }^{39} \mathrm{Ar}$ dates for alkaline rocks of the northern Crazy Mountains are somewhat older than biotite ${ }^{40} \mathrm{Ar} /{ }^{39} \mathrm{Ar}$ dates for the subalkaline Big Timber stock, which give apparent ages of about 49.2-49.3 Ma (du Bray and Harlan, 1996). This could be interpreted to indicate that the alkaline rocks of the northern Crazy Mountains predate emplacement of the subalkaline rocks exposed largely in the southern Crazy Mountains. This interpretation is problematic, however, because biotite dates from the Big Timber stock probably represent cooling ages through closure temperatures of about $350^{\circ} \mathrm{C}$ and thus represent minimum ages for emplacement of the stock. Intrusive relationships bearing on the relative ages of the two distinct geochemical groups are rare and typically ambiguous (Dudas, 1991), and they cannot be used to distinguish the relative ages of the two groups. The limited span of ${ }^{40} \mathrm{Ar} /{ }^{39} \mathrm{Ar}$ ages between the subalkaline and alkaline rocks (ca. 50.6-49.2 Ma) indicates that magmas represented by these two distinctly different geochemical groups were very closely associated in both time and space and may indicate that all of these rocks were emplaced in as little as 1.5 m.y. On a regional scale, the age span of 51-49 Ma is similar to that of most igneous centers of the central Montana alkalic province and is coeval with the peak of widespread volcanism in the Absaroka-Gallatin volcanic field directly to the south of the Crazy Mountains Basin.

\section{Whole-Rock Chemistry}

\section{Major-Oxide Data}

Extensive compositional variation, as exemplified by $\mathrm{SiO}_{2}$ abundances that range from 51 to 71 weight percent (table 1), is the most obvious feature of the Crazy Mountains dike swarm. Compositional variation among the dikes (fig. 5) is not quite as extensive as that of the presumably cogenetic Big Timber stock and less systematic than that displayed by the stock. In particular, the abundance array of $\mathrm{Na}_{2} \mathrm{O}+\mathrm{K}_{2} \mathrm{O}$ versus $\mathrm{SiO}_{2}$ for the dikes (fig. 3) is more diffuse than that for the stock (du Bray and Harlan, 1996; fig. 5). The diffuse nature of the alkali compositional array and petrographic features, indicating that many of the dikes were affected by late-stage alteration, suggest that the enhanced alkalinity of the dikes may be a secondary, nonmagmatic feature that resulted from magmatic-hydrothermal processes. Most dikes have alkaline to subalkaline compositions (as indicated by total alkali versus silica in the range between the alkalinesubalkaline dividing lines of Irvine and Baragar, 1971, and Le Bas and others, 1986), and the dikes, as a group, appear to be more alkaline than the stock. Many of the dikes have compositions that are truly alkaline, as indicated by total alkali versus silica that plots (fig. 3) above the alkaline-subalkaline dividing line of Le Bas and others (1986). The tendency toward alkaline compositions decreases in dikes having the highest $\mathrm{SiO}_{2}$ content. Most sample compositions plot in the high-potassium 



Figure 5. Variation diagrams showing abundances of major oxides and zirconium in samples from the Crazy Mountains dike swarm, south-central Montana. Discriminant line on $\mathrm{K}_{2} \mathrm{O}$ versus $\mathrm{SiO}_{2}$ diagram from Ewart (1982). 
calc-alkaline field (Ewart, 1982) on a $\mathrm{K}_{2} \mathrm{O}$ versus $\mathrm{SiO}_{2}$ diagram (fig. 5), and some plot in the shoshonitic series field. According to the classification scheme of Le Bas and others (1986), and because $\left(\mathrm{Na}_{2} \mathrm{O}-2\right)<\mathrm{K}_{2} \mathrm{O}$ in almost all of the dikes, the trachybasalt dikes are properly termed "potassic trachybasalt," the basaltic trachyandesite dikes are "shoshonite," and the trachyandesite dikes are "latite."

The phaneritic rocks of the Big Timber stock display a strong relationship between chemical composition and modal mineralogy. Similarly, rocks of the Crazy Mountains dike swarm display a strong relationship between composition and phenocryst suites (fig. 3). As previously indicated, samples of the dike swarm were assigned to groups on the basis of the types of contained phenocrysts; each group has a distinctive composition. A particularly noteworthy group of samples contains clinopyroxene and plagioclase as its principal phenocrysts. Samples containing these phenocrysts are distinguished by compositions that are at the low-silica, low-total-alkalis end of the compositional array formed by the dike swarm. A large subset of dike samples contains plagioclase, clinopyroxene, and magnesio-hastingsite as phenocrysts. These dikes contain low to intermediate abundances of silica and a distinctly higher abundance of total $\mathrm{Na}_{2} \mathrm{O}+\mathrm{K}_{2} \mathrm{O}$ than the group that contains clinopyroxene and plagioclase as its principal phenocrysts. Another geochemical subset of the dikes contains intermediate abundances of silica that are greater than those of the two previously described groups and also contain intermediate abundances of total $\mathrm{Na}_{2} \mathrm{O}+\mathrm{K}_{2} \mathrm{O}$; this group is petrographically noteworthy given its lack of clinopyroxene phenocrysts and the presence of only plagioclase and magnesio-hastingsite phenocrysts. The more evolved, higher silica dacite and rhyolite dikes are petrographically characterized by plagioclase, potassium feldspar, biotite, quartz, and varying combinations of clinopyroxene, magnesio-hastingsite, and magnesio-hornblende.

As is the case for most subalkaline rocks, abundances of $\mathrm{FeO}^{*}$ (total iron expressed as ferrous oxide), $\mathrm{MgO}, \mathrm{CaO}$, $\mathrm{TiO}_{2}, \mathrm{MnO}$, and $\mathrm{P}_{2} \mathrm{O}_{5}$ in samples of the Crazy Mountains dike swarm decrease with increasing $\mathrm{SiO}_{2}$, whereas abundances of $\mathrm{K}_{2} \mathrm{O}$ and $\mathrm{Na}_{2} \mathrm{O}$ increase (fig. 5). The abundance of $\mathrm{Al}_{2} \mathrm{O}_{3}$ increases from about 16 to 18 weight percent at $\mathrm{SiO}_{2}$ abundances of about 50 and 60 weight percent, respectively; $\mathrm{Al}_{2} \mathrm{O}_{3}$ abundances decrease gradually to about 15 weight percent at $\mathrm{SiO}_{2}$ abundances between 60 and 71 weight percent. None of the major-oxide variation arrays is strictly linear, and most display considerable dispersion. Variations in $\mathrm{FeO}^{*}, \mathrm{MgO}$, $\mathrm{CaO}, \mathrm{TiO}_{2}, \mathrm{MnO}$, and $\mathrm{P}_{2} \mathrm{O}_{5}$ abundances form concave-upward curvilinear patterns, whereas those of $\mathrm{K}_{2} \mathrm{O}$ and $\mathrm{Na}_{2} \mathrm{O}$ form concave-downward curvilinear patterns. Variations of $\mathrm{CaO}$ and $\mathrm{FeO}^{*}$ are the most systematic and nearly linear.

\section{Trace-Element Data}

Variations in trace-element abundance among samples of the Crazy Mountains dike swarm are considerably less pronounced than associated variations in major-oxide abundances.
Approximate minimum and maximum values, in parts per million, for selected trace elements in the dike samples, excluding rare compositional outliers, are as follows: $\mathrm{Rb}, 20$ and 80; $\mathrm{Sr}$, 400 and 1,300; Y, 10 and 35; Zr, 125 and 225; Nb, 15 and 30; $\mathrm{Ba}, 800$ and 1,500; La, 30 and 90; Ce, 60 and 120; and Nd, 10 and 70. As is true of the variations in major-oxide abundances, trace-element distributions are characterized by considerable dispersion and abundances are poorly correlated with $\mathrm{SiO}_{2}$ abundances. Abundances of $\mathrm{Sr}, \mathrm{Y}$, and $\mathrm{Nb}$ do not consistently covary with $\mathrm{SiO}_{2}$ abundances; they exhibit a weak tendency to decrease in samples having the highest $\mathrm{SiO}_{2}$ abundances. Abundances of $\mathrm{La}, \mathrm{Ce}$, and $\mathrm{Nd}$ show no correlation with varying $\mathrm{SiO}_{2}$ abundance. Abundances of $\mathrm{Ba}, \mathrm{Rb}$, and $\mathrm{Zr}$ are consistently greater in samples having higher $\mathrm{SiO}_{2}$ contents. The $\mathrm{Rb}-\mathrm{Sr}$ ratios for samples of the Crazy Mountains dike swarm are consistently low and range from 0.01 to 0.14 , averaging $0.07 \pm 0.04$.

\section{Discussion}

Granitoid magmas generated in different tectonic settings have distinct geochemical signatures (Pearce and others, 1984); these signatures help define the tectonic setting in which the Big Timber stock and its associated dike swarm developed. Trace-element abundances in the Crazy Mountains dike swarm, in particular those of $\mathrm{Rb}, \mathrm{Y}$, and $\mathrm{Nb}$, are similar to those of subduction-related volcanic arc rocks (fig. 6). Gill (1981) has shown that La-Nb ratios of 2-7 are also characteristic of magmas generated in a subduction-related volcanic arc setting. The



Figure 6. Trace-element tectonic setting-discrimination variation diagram for samples from the Crazy Mountains dike swarm, south-central Montana. Tectonic setting-composition boundaries from Pearce and others (1984). 


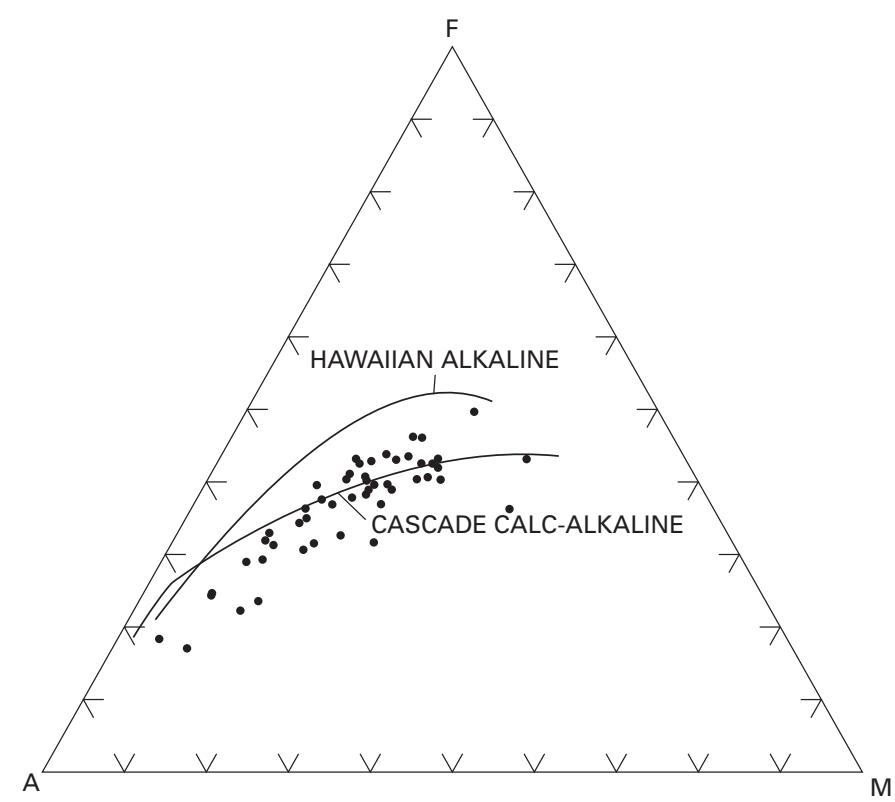

Figure 7. Ternary AFM $\left(\mathrm{Na}_{2} \mathrm{O}+\mathrm{K}_{2} \mathrm{O}-\mathrm{FeO}-\mathrm{MgO}\right)$ diagram showing compositions of samples from the Crazy Mountains dike swarm, south-central Montana. Cascade calc-alkaline and Hawaiian alkaline trend lines from Irvine and Baragar (1971).

La-Nb ratios for samples of the Crazy Mountains dike swarm (table 1) range from 1.2 to 5.9 and average $2.8 \pm 1$. Major-oxide compositions of the Crazy Mountains dike swarm approximate a calc-alkaline AFM $\left(\mathrm{Na}_{2} \mathrm{O}+\mathrm{K}_{2} \mathrm{O}-\mathrm{FeO}^{*}-\mathrm{MgO}\right)$ trend similar to that of modern Cascade volcanic arc rocks (fig. 7). These compositional characteristics are all similar to those exhibited by samples of the cogenetic Big Timber stock and are consistent with a mantle-dominated genesis in a subduction-related volcanic arc setting (du Bray and Harlan, 1996).

In igneous systems, abundances of $\mathrm{Sr}, \mathrm{K}$, and $\mathrm{Rb}$ are principally controlled by feldspar (Hanson, 1980); abundances of $\mathrm{Sr}$ and $\mathrm{Rb}$ are most and least, respectively, depleted by feldspar fractionation. As feldspar fractionation and differentiation proceed, $\mathrm{K}$ and, to an even greater extent, $\mathrm{Rb}$ are concentrated in the residual liquid relative to $\mathrm{Sr}$. Compositions plotting nearest the $\mathrm{Sr}$ apex of the $\mathrm{Rb}-\mathrm{K} / 100-\mathrm{Sr}$ ternary diagram (fig. 8) represent the least evolved magmas. Tight clustering of Sr abundances for samples of the Crazy Mountains dike swarm indicates that plagioclase (principal residence of $\mathrm{Sr}$ ) fractionation did not strongly affect $\mathrm{Sr}$ abundances in compositional evolution of the Crazy Mountains dike swarm. Samples of the Crazy Mountains dike swarm plot along a short array with an origin near the Sr apex; samples of the most and least evolved dikes plot farthest from and nearest to the $\mathrm{Sr}$ apex, respectively. The shortness and position of this array, near the Sr apex, also suggest that Sr abundances in the magma reservoir represented by the dike swarm were not strongly affected by plagioclase fractionation. The shortness of the compositional evolution array on the $\mathrm{Rb}-\mathrm{K} / 100-\mathrm{Sr}$ ternary diagram (fig. 8) also results from the significantly elevated $\mathrm{Sr}$ abundances characteristic of dike swarm samples (table 1); fractionation of plagioclase from a very Sr-rich magma causes the abundance of $\mathrm{Sr}$, relative to those of $\mathrm{K}$ and $\mathrm{Rb}$, in residual magma to be little affected. However, the role of plagioclase fractionation in the overall evolution of the reservoir represented by the dikes is indicated by covariations in $\mathrm{Al}_{2} \mathrm{O}_{3}$ and $\mathrm{SiO}_{2}$ abundances (fig. 5). Abundances of $\mathrm{Al}_{2} \mathrm{O}_{3}$ increase steadily in samples containing between about 50 and 60 percent $\mathrm{SiO}_{2}$. This can occur only if relatively $\mathrm{Al}_{2} \mathrm{O}_{3}-$ rich plagioclase composes less than half of the fractionating assemblage. The downturn in $\mathrm{Al}_{2} \mathrm{O}_{3}$ abundances in samples containing greater than 60 percent $\mathrm{SiO}_{2}$ denotes the point at which plagioclase fractionation becomes a controlling factor in compositional evolution of the residual liquid.

The spatial coincidence, contemporaneity, field relations, and similarity of petrographic and geochemical features combine to indicate that dikes of the Crazy Mountains dike swarm and the Big Timber stock are cogenetic and are simply different physical manifestations of magma derived from a single reservoir. The fact that essentially all of the compositional range depicted by the Big Timber stock is mimicked by dikes of the Crazy Mountains dike swarm indicates that the magma reservoir, represented by the solidified stock itself and from which magma represented by the dikes was extracted, was tapped continuously during all stages of its compositional evolution. Magma represented by various intrusions in the central Crazy Mountains was emplaced into a shallow crustal magma reservoir that formed a roughly diapiric body. Emplacement was accompanied by development of a quasi-radial fracture

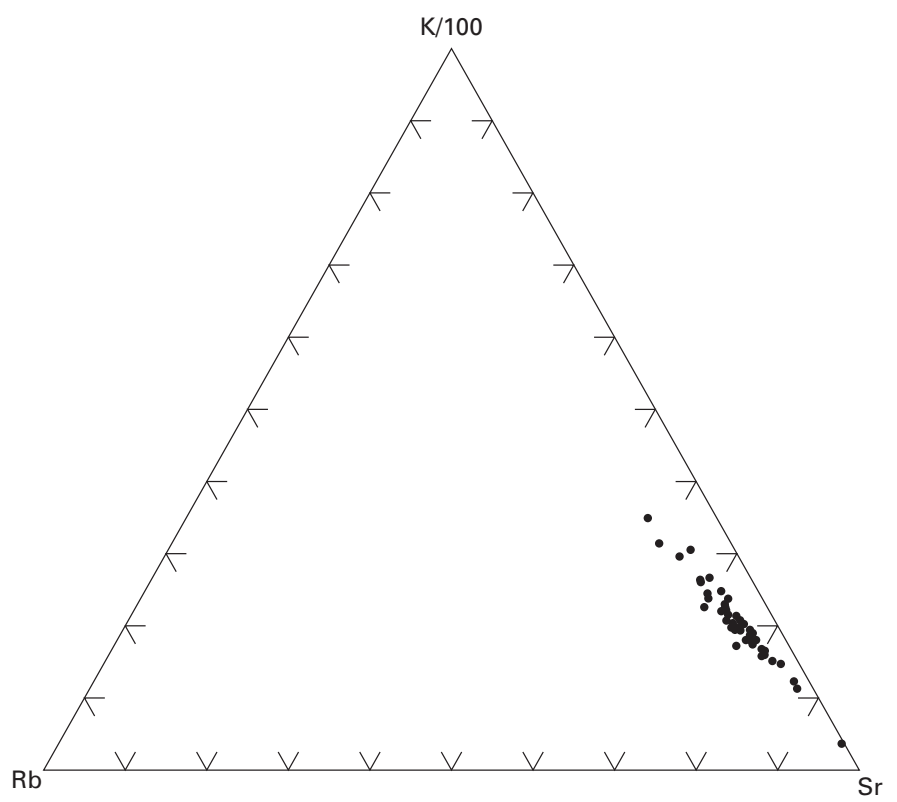

Figure 8. Ternary variation diagram showing the relative proportions of $\mathrm{Rb}, \mathrm{K}$, and $\mathrm{Sr}$ in samples from the Crazy Mountains dike swarm, south-central Montana. 
system in the overlying and enclosing roof and wall rocks. Brittle fractures that cut the rocks of the Fort Union Formation were affected by periodic dilation in response to a local tectonic stress field that varied as emplacement of the reservoir represented by the stock proceeded. During these dilation episodes, which must have occurred throughout the time required for the magma reservoir represented by the stock to achieve its full compositional diversity, magma was extracted from the underlying reservoir and emplaced upward into a radial array of tension fractures.

Given the conclusion that the dike swarm and the stock are cogenetic, the process of reservoir compositional evolution identified by du Bray and Harlan (1996) for the stock is likely equally applicable to the compositional diversity displayed by samples of the dike swarm. The identified process involves sidewall crystallization and fractionation of varying amounts of plagioclase, orthopyroxene, clinopyroxene, magnesiohastingsite, hornblende, biotite, titanite, apatite, zircon, and magnetite. Glomerocrysts found throughout samples of the dikes and stock indicate that mineral assemblages contained therein must have played an essential role relative to chemical evolution of the parent magma. Crystals nucleated along the walls and roof of the cooling magma reservoir while residual silicate liquid continued mixing; some previously formed crystals were plucked from the solidification front and remixed with residual liquid. Similarly, the tectonic regime in which the Big Timber stock evolved (du Bray and Harlan, 1996) must have prevailed during development of the dike swarm. The Eocene Big Timber stock and its associated dike swarm are manifestations of renewed volcanic arc magmatism following shallow subduction; these igneous rocks document the easternmost extent of arc magmatism at the onset of Eocene igneous activity and its subsequent westward migration in response to steepening subduction and westward hingeline retreat.

\section{Conclusions}

The Crazy Mountains dike swarm forms a radial array associated with the Eocene Big Timber stock in the Crazy Mountains of south-central Montana. The spatial coincidence, contemporaneity, field relations, and similarity of petrographic and geochemical features indicate that the dike swarm and the stock are cogenetic. Furthermore, ${ }^{40} \mathrm{Ar} /{ }^{39} \mathrm{Ar}$ data presented here and by du Bray and Harlan(1996) indicate that alkaline and subalkaline magmatism were approximately coeval. Dikes are hosted by the stock and by the same Fort Union Formation rocks that host the stock.

The dikes depict a broad array of compositional types from rhyolite to basalt; no well-developed preferential spatial distribution of dikes of any particular composition was identified. Dike samples contain from 51 to 71 weight percent $\mathrm{SiO}_{2}$, a range that, although similar to that exhibited by the stock, is not quite as extensive. Compositional variation among the dikes is less systematic than is characteristic of the stock; the dikes form more broadly diffuse compositional arrays and tend to be slightly more alkaline. Both of these factors could result from late-stage magmatic-hydrothermal processes that seem to have weakly altered many of the dikes. Major-oxide and trace-element characteristics of the dikes and the associated stock are consistent with a mantle-dominated genesis in a subduction-related volcanic arc setting. As discussed at length by du Bray and Harlan (1996), characteristics of this magmatic system are consistent with renewed volcanic arc magmatism during the Eocene westward hingeline retreat and with subsequent westward migration of the magmatic front in response to steepening subduction along the western edge of North America.

\section{References Cited}

Armstrong, R.L., 1978, Cenozoic igneous history of the U.S. Cordillera from lat. $42^{\circ}$ to $49^{\circ}$ N.: Geological Society of America Memoir 152, p. 265-282.

Armstrong, R.L., and Ward, P., 1991, Evolving geographic patterns of Cenozoic magmatism in the North American Cordillera-The temporal and spatial association of magmatism and metamorphic core complex formation: Journal of Geophysical Research, v. 96, p. 13201-13224.

Chadwick, R.A., 1972, Volcanism in Montana: Northwest Geology, v. 1, p. 1-20.

Dalrymple, G.B., and Lanphere, M.A., 1969, Potassium-argon dating: San Francisco, W.H. Freeman, 251 p.

du Bray, E.A., Elliott, J.E., Wilson, A.B., Van Gosen, B.S., and Rosenberg, L.A., 1993, Geologic map of the Big Timber stock and vicinity, southern Crazy Mountains, Sweet Grass and Park Counties, south-central Montana: U.S. Geological Survey Miscellaneous Field Studies Map MF-2253, scale $1: 24,000$.

du Bray, E.A., and Harlan, S.S., 1996, The Eocene Big Timber stock, south-central Montana: Development of extensive compositional variation in an arc-related intrusion by side-wall crystallization and cumulate glomerocryst remixing: Geological Society of America Bulletin, v. 108, p. 1404-1424.

Dudas, F.O., 1990, Petrogenesis and mantle source of igneous rocks in the Crazy Mountains, Montana: University Park, Pennsylvania State University, Ph.D. thesis, 442 p.

Dudas, F.O., 1991, Geochemistry of igneous rocks from the Crazy Mountains, Montana, and tectonic models for the Montana alkalic province: Journal of Geophysical Research, v. 96, p. 13261-13277.

Elsass, Francoise, and du Bray, E.A., 1982, Energy-dispersive X-ray fluorescence spectrometry with the Kevex 7000 system: Saudi Arabian Deputy Ministry Mineral Resources Open-File Report USGS-OF-02-52, 53 p. 
Ewart, Anthony, 1982, The mineralogy and petrology of Tertiary-Recent orogenic volcanic rocks with special reference to the andesitic-basaltic compositional range, in Thorpe, R.S., ed., Andesites: Chichester, England, John Wiley, p. 25-87.

Feeley, T.C., 2003, Origin and tectonic implications of acrossstrike geochemical variations in the Eocene Absaroka volcanic province, United States: Journal of Geology, v. 111, p. 329-346.

Fleck, R.J., Sutter, J.F., and Elliott, D.H., 1977, Interpretation of discordant ${ }^{40} \mathrm{Ar} /{ }^{39} \mathrm{Ar}$ age spectra of Mesozoic tholeiites from Antarctica: Geochimica et Cosmochimica Acta, v. 41, p. 15-32.

Gill, James, 1981, Orogenic andesites and plate tectonics: New York, Springer-Verlag, 390 p.

Hanson, G.N., 1980, Rare earth elements in petrogenetic studies of igneous systems: Annual Review of Earth and Planetary Sciences, v. 8, p. 371-406.

Hardyman, R.F., 1989, Eocene magmatism, Challis volcanic field, central Idaho, in Hyndman, D.W., ed., Cordilleran volcanism, plutonism, and magma generation at various crustal levels, Montana and Idaho: American Geophysical Union Field Trip Guidebook T337, p. 32-41.

Harlan, S.S., 1986, Timing of deformation along the leading edge of the Montana disturbed belt, northern Crazy Mountains Basin, Montana: Bozeman, Montana State University, M.Sc. thesis, $87 \mathrm{p}$.

Harlan, S.S., Geissman, J.W., Lageson, D.R., and Snee, L.W., 1988, Paleomagnetic and isotopic dating of thrust belt deformation along the eastern edge of the Helena salient, northern Crazy Mountains, Montana: Geological Society of America Bulletin, v. 100, p. 492-499.

Irvine, T.N., and Baragar, W.R.A., 1971, A guide to the chemical classification of the common volcanic rocks: Canadian Journal of Earth Sciences, v. 8, p. 523-548.

Janecke, S.U., and Snee, L.W., 1993, Timing and episodicity of middle Eocene volcanism and onset of conglomerate deposition, Idaho: Journal of Geology, v. 101, p. 603-621.

Larsen, E.S., 1940, Petrographic province of central Montana: Geological Society of America Bulletin, v. 51, p. 887-948.

Le Bas, M.J., Le Maitre, R.W., Streckeisen, A.L., and Zanettin, B., 1986, A chemical classification of volcanic rocks using the total alkali-silica diagram: Journal of Petrology, v. 27 , p. 745-750.

O’Brien, H.E., Irving, A.J., and McCallum, I.S., 1991, Eocene potassic magmatism in the Highwood Mountains, Montana-Petrology, geochemistry, and tectonic implications: Journal of Geophysical Research, v. 96, p. 1323713260.
O’Brien, H.E., Irving, A.J., McCallum, I.S., and Thirlwall, M.F., 1995, Strontium, neodymium, and lead isotopic evidence for the interaction of post-subduction asthenospheric potassic magmas of the Highwood Mountains, Montana, USA, with ancient Wyoming craton lithospheric mantle: Geochimica et Cosmochimica Acta, v. 59, p. 4539-4556.

Pearce, J.A., Harris, N.B.W., and Tindle, A.G., 1984, Trace element discrimination diagrams for the tectonic interpretation of granitic rocks: Journal of Petrology, v. 25, p. 956-983.

Roberts, A.E., 1972, Cretaceous and early Tertiary depositional and tectonic history of the Livingston area, southwestern Montana: U.S. Geological Survey Professional Paper 526-C, 120 p.

Samson, S.D., and Alexander, E.C., Jr., 1987, Calibration of the interlaboratory ${ }^{40} \mathrm{Ar}-{ }^{39} \mathrm{Ar}$ dating standard, MMhb-1: Chemical Geology, v. 66, p. 27-34.

Simms, F.E., 1966, The igneous petrology, geochemistry, and structural geology of part of the northwestern Crazy Mountains, Montana: Cincinnati, Ohio, University of Cincinnati, Ph.D. thesis, 339 p.

Smedes, H.W., and Prostka, H.J., 1972, Stratigraphic framework of the Absaroka Volcanic Supergroup in the Yellowstone National Park region: U.S. Geological Survey Professional Paper 729-C, 33 p.

Snee, L.W., 2002, Argon thermochronology of mineral deposits - A review of analytical methods, formulations, and selected applications: U.S. Geological Survey Bulletin 2194, 39 p.

Starmer, R.J., 1972, The distribution and geochemistry of the Big Timber dike swarm, Crazy Mountains, Montana: Cincinnati, Ohio, University of Cincinnati, Ph.D. thesis, 90 p.

Steiger, R.H., and Jäger, E., 1977, Subcommission on geochronology-Convention on the use of decay constants in geo- and cosmochronology: Earth and Planetary Science Letters, v. 36, p. 359-362.

Streckeisen, A.L., 1973, Plutonic rocks, classification and nomenclature recommended by the IUGS subcommission on the systematics of igneous rocks: Geotimes, v. 18, no. 10 , p. 26-30.

Taggart, J.E., Lindsay, J.R., Scott, B.A., Vivit, D.V., Bartel, A.J., and Stewart, K.C., 1987, Analysis of geologic materials by X-ray fluorescence spectrometry, chap. E of Baedecker, P.A., ed., Methods for geochemical analysis: U.S. Geological Survey Bulletin 1770, p. E1-E19.

Tappe, John, 1966, The chemistry, petrology, and structure of the Big Timber igneous complex, Crazy Mountains, Montana: Cincinnati, Ohio, University of Cincinnati, Ph.D. thesis, $134 \mathrm{p}$. 
Taylor, J.R., 1982, An introduction to error analysis: Mill Valley, Calif., University Science Books, 270 p.

Wolff, J.E., 1892, The geology of the Crazy Mountains, Montana: Geological Society of America Bulletin, v. 3, p. $445-452$.
Wolff, J.E., 1938, Igneous rocks of the Crazy Mountains, Montana: Geological Society of America Bulletin, v. 49, p. $1569-1626$.

Yager, D.B., and Quick, J.E., 1992, Superxap manual: U.S. Geological Survey Open-File Report 92-13, 45 p.
Published in the Central Region, Denver, Colo.

Manuscript approved for publication August 24, 2005

Graphics by the author and by Springfield and Springfield (Contractor)

Photocomposition by Mari L. Kauffmann (Contractor, ATA Services)

Edited by Diane E. Lane 